RUNNING HEAD: ADULT ATTACHMENT AND SOCIAL ANXIETY

\title{
A systematic review of adult attachment and social anxiety
}

Ray P. C. Manning ${ }^{1,2 *}$; Alexandra Cunliffe ${ }^{3}$, Jasper Palmier-Claus ${ }^{4,5}$, Joanne Dickson $^{1,6}$, Peter J. Taylor ${ }^{1,5}$

${ }^{1}$ Institute of Psychology, Health \& Society, University of Liverpool, Liverpool, England, L69 3GB

${ }^{2}$ Wigan CAMHS, Manchester Road, Higher Ince, Wigan, WN2 2JA

${ }^{3}$ Liverpool Reviews and Implementation Group, University of Liverpool, Liverpool, England, L69 3GB

${ }^{4}$ The Psychosis Research Unit, Bury New Road, Prestwich, Manchester, England, M25 3BL ${ }^{5}$ Institute for Brain, Behaviour \& Mental Health, University of Manchester, Manchester, UK. ${ }^{6}$ Edith Cowan University, Australia

*Corresponding author:

The University of Liverpool

Institute of Psychology, Health and Society

The Whelan Building

Brownlow Hill

Liverpool

L693GB

Tel: 01517745530

Email: RManning27@gmail.com 


\begin{abstract}
Background: Attachment has been implicated in the development of social anxiety. Our aim was to synthesise the extant literature exploring the role of adult attachment in these disorders.

Method: Search terms relating to social anxiety and attachment were entered into MEDLINE, PsycINFO and Web of Science. Risk of bias of included studies was assessed using and adapted version of the Agency for Healthcare Research and Quality assessment tool. Eligible studies employed validated social anxiety and attachment assessments in adult clinical and analogue samples. The review included cross sectional, interventional and longitudinal research.

Results: Of the 30 identifies studies, 28 showed a positive association between attachment insecurity and social anxiety. This association was particularly strong when considering attachment anxiety. Cognitive variables and evolutionary behaviours were identified as potential mediators, concordant with psychological theory.
\end{abstract}

Limitations: Due to a lack of longitudinal research, the direction of effect between attachment and social anxiety variables could not be inferred. There was substantial heterogeneity in the way that attachment was conceptualised and assessed across studies.

Conclusions: The literature indicates that attachment style is associated with social anxiety. Clinicians may wish to consider attachment theory when working clinically with this population. In the future, it may be useful to target the processes that mediate the relationship between attachment and social anxiety.

Keywords: Social Anxiety; Attachment; Review; Social Phobia; Adults 


\section{Highlights}

- Adult attachment is associated with social anxiety.

- Cognitive and behavioural variables may mediate adult attachment and social anxiety.

- Insufficient evidence exists to infer causality in these relationships.

- Attachment is a varied construct measured using a range of techniques. 


\section{Introduction}

Social anxiety is the fear of or anxiety in response to social interactions or performance situations that is out of proportion to the actual threat of this experience (NICE, 2013). It is reported as the second most common anxious condition with a lifetime prevalence of $6.7 \%-10.7 \%$ in western countries (Fehm, et al., 2005; Kessler, Petukhova, et al., 2012). When considered on a continuum, less pervasive/distressing social anxiety, in the form of shyness or behavioural inhibition, may extend to more than half of the population during adolescence/early adulthood (Aderka, et al., 2012; Henderson, et al., 2014). At greater severities, social anxiety has high comorbidity with other psychosocial problems, such as depression (Beesdo et al., 2007) and other anxiety conditions (Kessler, Avenivoli, et al., 2012). It is also associated with impairments to quality of life (Wittchen \& Jacobi, 2005), romantic relationships (Sparrevohn \& Rapee, 2009) and friendships (Davila \& Beck, 2002). Numerous therapeutic approaches to treating social anxiety have now been evidenced (MayoWilson et al., 2014). Though there is evidence of efficacy for pharmacological (Standardised Mean Difference $[\mathrm{SMD}]=-.91,95 \% \mathrm{CI}=-1.23$ to -.60$)$ and psychological treatment $(\mathrm{SMD}$ $=-1.19,95 \% \mathrm{CI}=-1.56$ to -.81 ; Mayo-Wilson et al., 2014), understanding underlying psychological mechanisms associated with the development and maintenance of social anxiety might provide an opportunity for earlier intervention/prevention and developing more effective treatments. This review focuses on one potential mechanism, attachment.

Attachment theory posits that humans are motivated to form affective bonds with others when vying for safety, comfort and protection (Bowlby, 1988). We form 'internal working models' (IWMs) from interpersonal interaction, which generate implicit rules for understanding ourselves, others and how the two interact. Primary caring relationships are considered central to the development of IWMs (Bowlby, 1988), but peer and romantic relationships are also potentially important (Hazan \& Shaver, 1987; Pierce \& Lydon, 2001; 
Davila \& Sargent, 2003; Fraley, et al., 2013). Sensitive and attuned interactions with caregivers and important others, particularly in response to distress, can result in secure attachment, and IWMs of self as loveable and able, and others as caring and reliable. Neglectful or abusive interactions with others can result in insecure attachments and IWMs of self as worthless and inept, and/or others as abusive and untrustworthy (Bretherton \& Munholland, 1999). Attachment style throughout life can be characterised by IWMs about self and others, guiding individual behaviour based on the extent to which a person seeks or avoids attachment experiences (Brennan, et al., 1998).

Insecure attachment styles have traditionally been divided into anxious-ambivalent and avoidant attachment styles (Ainsworth et al., 1978; Hazan \& Shaver, 1987). Notably, the terms preoccupied and dismissive have also been used to refer to anxious and avoidant patterns in adults, respectively. One of the first assessments of attachment in adulthood, the Adult Attachment Interview (AAI; Main, Goldwyn \& Hesse, 2003) relies on an assessment of the quality and form of individual's interview narratives. Other approaches have focused on self-report appraisals of attachment experiences (e.g., Bartholomew, 1990; Brennan, et al., 1998).

Theory links attachment styles to differences in IWMs of self and other (Bartholomew, 1990; Ravitz, et al., 2010). Anxious attachment style is characterised by negative IWMs of self (i.e. seeing self as unlovable) whilst avoidant attachment style is characterised by negative IWMs of others (i.e., seeing others as untrustworthy; Ravitz, et al., 2010). Dimensional models see anxiety and avoidance as the two main continua of attachment experience, which underlie the presence of specific styles (Bartholomew, 1990; Brennan, et al., 1998). A more severe, 'fearful-avoidant' attachment style has also be suggested, characterised by high levels of both attachment avoidance and anxiety (Bartholomew, 1990). 
Past research describes the desire for attachment as fundamental to human experience (Baumeister \& Leary, 1995). IWMs that embody expectations of rejection from others may understandably result in anxiety in social situations, despite still feeling a drive for attachment. Inasmuch as this IWM informs how social situations are viewed and interpreted, insecure attachment may result in a hypervigilance to signs of rejection or threat, and biased threat-related appraisals in social situations. Thus, attachment may play a key role in the development of social anxiety.

Vertue (2003) posits a unifying theory linking evolutionary, self-presentation and learning theories of social anxiety through the lens of attachment to explain the origins, development and maintenance of social anxiety. Vertue's hypothesises that early life experiences can result in IWMs of self as inferior, undesirable, low in social-status (Ollendick \& Benoit, 2012; Brumariu, et al., 2013), and models of others as rejecting. These activate evolutionary behaviours of submission to and avoidance of others, which induce and reinforce anxiety in social domains (Weisman, et al., 2011). This in turn could influence adult attachment security reinforcing avoidance and overestimation of social risks (Fraley et al., 2013). Conceptually, this theory compliments cognitive models of social anxiety (Clark \& Wells, 1995), wherein underlying schemata of self and others result in appraisals of social situations as threatening, leading to self-monitoring and avoidant safety behaviours.

Child and adolescent samples have demonstrated the importance of attachment alongside parenting style, social competence and behavioural inhibition in the development of social anxiety (Cunha, et al., 2008; Brumariu \& Kerns, 2008; 2010). Early adulthood has been associated with a spike in anxious symptomology, which may be related to significant social and environmental change during this period (Copeland, et al., 2014). Understanding how attachment may influence the development and maintenance of social anxiety in adulthood could lead to more effective assessment and intervention, alleviating suffering and 
minimising the potential development of comorbid problems (Stein et al., 2001; Beesdo et al., 2007). This literature review aims to evaluate the evidence in the extant literature of an association between adult attachment and social anxiety symptoms.

\section{Method}

The protocol is pre-registered and available on the PROSPERO data repository website: http://www.crd.york.ac.uk/PROSPERO/display_record.asp?ID=CRD42016032991 registration number: CRD42016032991.

\section{Study Eligibility}

Eligible studies included: i) an adult sample, with a mean age of 18 years or older; ii) a quantitative self-report or interview measure of attachment and social anxiety or a clinical diagnoses of social anxiety disorder; iii) analysis of the relationship between attachment and social anxiety; iv) a cross-sectional, intervention, or longitudinal study design; and v) publication in English. We included studies measuring attachment prior to adulthood providing that social anxiety was measured in adulthood. Qualitative studies, reviews, editorials and case studies/case series were excluded. Studies explicitly considering social anxiety as related to autistic spectrum conditions were also excluded from this review.

\section{Search strategy}

Electronic searches of MEDLINE, PsycINFO and ISI Web of Science databases (from earliest records until January 2016) were conducted using the following search terms, combined with Boolean operators: Attach* AND ("Soc* Anx*" OR "Soc* Phob*" OR “SAD"). 
Initially, two reviewers (RM, AC) independently screened titles and abstracts of all identified articles. They then further screen the selected full articles with disagreements arbitrated by a third reviewer (PT). In addition to article identified through the systematic search, the authors checked the reference lists and citing articles of all included studies. The corresponding authors of included articles and two experts in the field were approached regarding any additional published or unpublished papers that might fit the inclusion criteria (Appendix A). RM also contacted the authors of all identified conference abstracts.

\section{Risk of Bias}

Included studies were assessed using a methodological quality assessment tool for observational research, adapted from one used by the Agency for Healthcare Research and Quality (AHRQ; Williams, et al., 2010; Appendix B) and elsewhere (Taylor, Hutton \& Wood, 2014).

\section{FIGURE 1 AROUND HERE}

\footnotetext{
Results

Due to in the wide variety of measures and definitions of attachment (13 different measures) and social anxiety (15 different measures), aggregation of effect sizes would be limited by high heterogeneity and low precision and so meta-analysis was not used here. Therefore, the results were synthesised narratively. Studies were grouped into four (not mutually-exclusive) categories. These included: Studies that compared social anxiety between attachment groups or attachment between social anxiety and control $(k=13)$; studies that examined within group associations $(k=23)$; studies that produced a moderation or
} 
mediational model of the relationship between attachment and social anxiety $(k=10)$; and longitudinal studies $(k=3)$.

\section{Study Characteristics}

Attachment and social anxiety were rarely the primary focus of included papers and only sample sizes, measures, data and outcomes relevant to this review are reported. Table 1 summarises the characteristics of the studies included in this review. Sample sizes ranged from $n=51$ to $n=8080$. Most studies took place in the USA, with others occurring in western (UK, Sweden, Switzerland, Netherlands, Italy, Germany, Canada) and middleeastern (Turkey, Israel) countries, with one study in China. Different forms of the Experiences in Close Relationships scale (Brennan, et al., 1998) were the most common means of assessing attachment (used in $k=13$ studies). In total 13 measures of attachment were used, including one behavioural measure (Strange situation, Ainsworth et al., 1978) and one interview measure (Attachment Style Interview, ASI; Bifulco et al., 1998). Measures of social anxiety also varied with the Liebowitz Social Anxiety Scale (LSAS; Liebowitz, 1987) used in $k=10$ studies and the Social Interaction Anxiety Inventory (SIAS; Mattick \& Clarke, 1998) used in $k=9$ studies. In total, 15 measures of social anxiety were used, including two interview measures collectively used in $k=5$ studies.

Of the different conceptualisations of attachment, $k=14$ studies used a dimensional model of attachment anxiety and attachment avoidance (Brennan, et al., 1998). Bartholomew's (1990) categorical model of secure, preoccupied, fearful and dismissive attachment styles was the theoretical basis for $k=9$ studies. Models of attachment conceptualising secure, anxious-ambivalent and avoidant styles (Ainsworth et al., 1978; Hazan \& Shaver, 1987; Collins, 1996) were the basis for $k=3$. Two studies conceptualised attachment on a single continuum from insecure to secure attachment. Bifulco and colleagues 
(2006) used an interview assessment of attachment, and conceptualised 'Secure, Enmeshed, Fearful, Angry-dismissive, Withdrawn' attachment styles.

\section{TABLE 1 AROUND HERE}

\section{Risk of Bias}

The risk of bias assessment for each study is presented in Table 2. Common methodological problems included justification of sample size, lack of clarity or justification for recruitment population or strategy, and control or consideration of confounding variables in analyses. All but one study failed to justify their sample size using a power analysis and may have been underpowered, raising the probability of a type-II error. In some cases large sample sizes mean that power was unlikely to have been an issue (e.g., Mickelson, et al., 1997; McDermott et al., 2012). However, six studies included participant numbers below 90, and two of these also used structural equation modelling, a technique requiring larger samples (Weisman, et al., $2011-n=87$; Gajwani, et al., $2013-n=51$ ). Not having stated a power calculation for statistical analyses, these results must be interpreted with caution.

Several studies $(k=15)$ recruited participants exclusively from undergraduate university courses which increased the possibility of cohort effects (i.e. level of education, socio-economic status, ethnicity). Several studies $(k=12)$ failed to control for covariates associated with social anxiety and/or attachment. For example, though depression was highly associated with social anxiety and attachment in the included literature $(k=7)$, other studies failed to control for this association, meaning the relationship between social anxiety and attachment may be confounded by uncontrolled variables. 
Measures of attachment and social anxiety occasionally lacked rigour $(k=9)$, with some studies using older scales or subscales not intended for individual use. Most studies assessed attachment and social anxiety at one time point using self-report questionnaires, limiting researcher-related bias. However, studies using face-to-face measures $(k=5)$, or assessing at sequential time points $(k=3)$, without discussing blinding of assessors researchers may have influenced responding or interpretation. Assessors may have been biased in their ratings based on their understanding of participants' attachment styles or social anxiety. Additionally, few papers $(k=8)$ stated whether the assumptions underlying their analyses were met. Consequently, it is unclear whether their analyses are appropriate and results valid.

TABLE 2 AROUND HERE

TABLE 3 AROUND HERE

\section{Attachment and Social Anxiety}

In total, 28 studies reported some significant association between attachment and social anxiety. Effect sizes ranged from negligible, $d=0.00$, to large, $d=1.76$ and $r=.616$.

Between group differences. Six studies compared attachment across groups defined by clinical 'caseness' for social anxiety. In five of these, people meeting diagnostic criteria for social anxiety were significantly more likely to be insecurely attached in comparison with healthy control groups $(O R=18.5 ; d=0.49-1.38$; Eng et al. 2001; Lionberg, 2003;

Weisman et al., 2011; Michail \& Birchwood, 2014). However, Kashdan and Roberts (2011) observed no difference in attachment to therapeutic group and therapist between depressed service-users with or without social anxiety. This difference may be due to the specific focus 
on attachment to therapeutic group, as opposed to romantic partners or parents, as in other studies. In particular, people with social anxiety reported higher attachment anxiety $(d=1.15$ - 1.45), lower comfort in closeness with attachment figures $(d=1.15-1.44)$ and lower ability to trust and depend on attachment figures than healthy controls $(d=0.45-1.02)$. A large effect size $(O R=18.5)$ was found in a small sample of individuals at ultra-high risk for psychosis (Michail \& Birchwood, 2014). This estimate was based on a low cell count and so lacks precision and may not be reliable.

One well-powered study compared differences in social anxiety between anxious and avoidant attachment style groups, finding no difference between these groups, but a significant association of both with social anxiety $(b=.52, \mathrm{p}<.001$; Mickelson, et al., 1997). However, the categorical assessment of attachment used in this study was very limited (Shi, et al., 2013).

Two studies did not show a significant difference in attachment anxiety between social anxiety groups and other anxiety disorder groups (Lionberg, 2003; Weisman et al., 2011). However, elevated attachment avoidance $(d=1.15$; Weisman et al., 2011) and reduced comfort with closeness to attachment figures ( $d=-0.71$; Lionberg, 2003) continued to distinguish socially anxious individuals from other anxiety groups.

In seven studies attachment was grouped into secure, preoccupied, dismissive and fearful styles, with comparisons made between these groups. Significant differences in social anxiety measures between groups suggested a relationship between attachment and social anxiety. When styles were directly compared $(k=2)$, fearful attachment and secure attachment demonstrated the greatest difference in social anxiety scores $(d=0.88-1.76)$ with greater social anxiety in the fearful attachment group and less in the secure attachment group (van Buren \& Cooley, 2002; Gajwani, et al., 2013). Secure attachment groups also tended to have lower levels of social anxiety than preoccupied/anxious $(d=0.86-1.30)$, and 
to a lesser extent dismissive/avoidant attachment groups $(d=0.36-0.51)$ suggesting dismissive/avoidant attachment has a weaker relationship with social anxiety scores.

Within group differences. Fourteen studies explored cross-sectional correlations between attachment and social anxiety. All found a significant relationship, wherein attachment insecurity was positively correlated with social anxiety. Where attachment was considered on a single continuum from insecure to secure $(k=7)$, attachment was positively associated with social anxiety with correlations ranging from $r=.17$ to $r=.62$.

Significant effects disappeared when four studies controlled for other covariates (e.g., social comparison, submissive behaviour, depression, parenting style), with associations between overall attachment security and social anxiety ranging from $\beta=-.11$ to $\beta=-.23$ (Anhalt \& Morris, 2008; Aderka et al., 2009; Parade, et al., 2010; Gajwani, et al., 2013). Anhalt and Morris (2008) reported the lowest effect size between attachment to parents and social anxiety, when controlling for ratings of perceived parenting style and perceived attitudes towards parenting. Arguably, these constructs could be thought to significantly overlap with or even mirror parental attachment. Additionally, attachment to parents in young adults may play a less important role in adult social anxiety.

Findings were inconsistent when considering attachment anxiety and avoidance separately $(k=9)$. Overall effects were slightly larger between social anxiety and attachment anxiety $(r=.23-.52 ; \beta=.06-.41)$ than attachment avoidance $(r=.02-.49 ; \beta=.06-.33)$. However, when controlling for cognitive features (i.e. flexibility, locus of control, repetitive thinking), or evolutionary behaviour variables (i.e. submissive behaviour; social comparison), studies $(k=3)$ found slightly higher associations between social anxiety and attachment avoidance $(\beta=.16-.33)$ in comparison with attachment anxiety $(\beta=.06-.21$; Weisman et al., 2011; Dağ \& Gülüm, 2013; Gülüm \& Dağ, 2013). 
In one study differences in effect size between attachment anxiety $(\beta=.11)$ and attachment avoidance $(\beta=.10)$ are negligible (Boelen, et al., 2014). Boelen et al. (2014) found that when inhibitory intolerance of uncertainty, comparable to behavioural inhibition, and neuroticism were controlled, attachment anxiety and avoidance had no remaining relationship with social anxiety.

Where attachment was broken into secure, preoccupied, dismissive and fearful styles $(k=5)$, having a secure attachment style was strongly, negatively associated with social anxiety $(k=4 ; r=-.42--.44 ; \beta=-.27--.48)$. Fearful attachment style was positively associated with social anxiety $(k=5 ; r=.09-.45 ; O R=23.2)$. However, two studies found non-significant relationships between social anxiety and fearful attachment style (Darcy, et al., 2005; Nikitin \& Freund, 2010). Nikitin and Freund (2010) found the strongest predictor of social anxiety was secure attachment with a non-significant effect for fearful attachment, when controlling for social approach and avoidance motivation, as well as the other attachment categories.

Moderation and mediation. Nine cross-sectional studies tested indirect effects wherein the relationship between attachment and social anxiety was mediated by other variables. Significant indirect effects were reported with mediators including cognitive flexibility (Dă̆ \& Gülüm, 2013), depression (Gajwani et al., 2013), social comparison, submissive behaviour (Aderka et al., 2009), locus of control, repetitive thinking (Gülüm \& Dağ, 2013), hope (McDermott et al., 2015), social approach motivation and social avoidance motivation (Nikitin \& Freund, 2010), and perceived social support (Roring, 2008). The association or overlap between these potential mediators was not fully assessed, however.

In contrast with Gajwani et al. (2013) who suggested depression mediates the link between attachment and social anxiety, other research has suggested that social anxiety mediates the relationship between attachment and depression (Eng et al., 2001; Aderka et al., 
2009; Weisman et al., 2011). These contrasting findings likely reflect the limitations of testing mediational effects in cross-sectional data, where direction of effect cannot be established.

One study found that the relationship between attachment and social anxiety was moderated by race, with Caucasian students found to have less association between social anxiety and attachment than other ethnicities (Parade, et al., 2010). High attrition and lack of control for social anxiety limit the generalisability of these findings. The university in which this study took place could have influenced the role of race in attachment and social anxiety, as non-Caucasian students were a minority group (70\% Caucasian; Parade, et al., 2010).

Longitudinal studies. Three studies explored the relationship between adult attachment and social anxiety over time suggesting a small effect size $(r=.17-.25)$. Bifulco et al. (2006) selected participants with a greater risk for psychosocial difficulties due to traumatic earlier life-experiences. They reported a small but significant relationship between attachment and social anxiety in participants with no prior experiences of social anxiety $(r=$ .17). Bohlin and Hagekull (2009) found no significant association between attachment measured in infancy using the 'strange situation' (Ainsworth et al., 1978), and adult social anxiety. In this study the correlation between infant attachment and social anxiety in adulthood (21 years) was likely attenuated by the time delay between assessments.

Despite a positive association between attachment and social anxiety, and the observed moderating effect of race on this relationship, the third study failed to control for social anxiety at assessment time one, meaning this finding is essentially cross-sectional despite the longitudinal design. 


\section{Discussion}

This review synthesises literature exploring the relationship between attachment and social anxiety. Of the 30 identifies studies, 28 showed a positive association between attachment insecurity and social anxiety. Effects became less consistent when adjusting for covariates. Longitudinal evidence that attachment style impacts on social anxiety was extremely limited, making the direction of relationships unclear and causality impossible to establish. The findings suggest that attachment experiences and learned behaviours may play a key role in the development social anxiety.

Attachment security was typically linked to lower social anxiety, whilst insecure attachment was associated with greater social anxiety across studies. There was some indication that preoccupied or anxious attachment styles were more strongly associated with social anxiety than dismissive or avoidant attachment styles, though this was not directly compared using post-hoc analyses. Attachment anxiety therefore may play a more substantive role than avoidance in the relationship between attachment and social anxiety. This is consistent with findings between attachment and social anxiety in children and adolescents (i.e. Brumariu \& Kerns, 2008; 2010; Brumariu, et al., 2013). However, when both attachment anxiety and avoidance are high, as in fearful attachment styles, an even stronger association with social anxiety was observed. Several studies found that when controlling for cognitive or evolutionary behaviour variables, attachment anxiety was no longer significantly predictive of social anxiety, whilst attachment avoidance maintained a significant relationship

(Weismann et al., 2011; Dağ, \& Gülüm, 2013; Gülüm \& Dağ, 2013). This may indicate the relationship between social anxiety and attachment anxiety is a function of cognitive or evolutionary variables, though the direction of this effect is not clear from cross-sectional data. This possibility is supported by the reviewed studies that tested mediational models involving these variables. 
One study (Roring, 2008) posits perceived social support as a potential mediator of the relationship between attachment and social anxiety, though the size of this relationship is not reported. This link may be understood through attachment style influencing the quality of actual interpersonal relationships, resulting in fewer contacts, lower trust or greater dependency, all of which could affect actual social support. Equally attachment style may exert an influence over the perception of social support, as mistrust of others, or feelings of inadequacy could colour the interpretation of social events as less supportive. Further research in this area will illuminate the role of actual and perceived social support to greater effect.

Findings support an attachment-based theoretical conceptualisation of social anxiety, which incorporates evolutionary and cognitive underlying factors (Vertue, 2003). Attachment anxiety theoretically involves negative IWMs of self, which could lead to social anxiety both by informing expectations of social rejection (i.e., informing threat appraisals) and also guiding behavioural tendencies to avoid feared rejection by exaggerating affect (not necessarily consciously). In this review cognitive and evolutionary variables (e.g. cognitive flexibility; intolerance of uncertainty; social comparison; behavioural inhibition) were suggested as potential mediators of the relationship between attachment anxiety and social anxiety, in line with cognitive and evolutionary theories of social anxiety (i.e., Gilbert, 2000; Clark \& Wells, 1995). In contrast, people high in attachment avoidance theoretically hold negative IWMs of others (e.g., others as untrustworthy) which could inform expectations of rejection or hostility. This could explain links to social anxiety observed in the included literature, which are contradictory to child and adolescent research into attachment and social anxiety (Brumariu \& Kerns, 2008; 2010). As fearful attachment styles theoretically involve negative IWMs of both self and other (Ravitz et al., 2010) its association with social anxiety may occur via both the pathways outlined above. As such, contextual influences that vary 
moment-to-moment warrant greater focus in trying to understand the association between attachment and social anxiety.

The included studies also support research suggestions (Ruscio, 2010) to conceptualise a continuum of social anxiety symptoms based on severity of symptoms, functional impairment and distress. Clinical levels of social anxiety were associated with greater attachment insecurity, particularly fearful attachment styles. However, common processes were observed underlying non-clinical and potentially prodromal social anxiety symptoms as participants beyond arbitrary clinical thresholds.

The existing literature is largely cross-sectional, limiting inferences about direction of the relationship between attachment and social anxiety. Longitudinal studies provided mixed evidence with small effect sizes, despite theory hypothesising clear causal associations (Vertue, 2003). Links between attachment and social anxiety were rarely the focus of longitudinal research, which was itself limited. This suggests the need for much greater investigation of this relationship in future work. No association was observed between infant attachment and adult social anxiety, though research has suggested this relationship may be attenuated by environment and interactions influencing attachment throughout life (Fraley et al., 2013). Additionally, lower associations between parental attachment and social anxiety in young adults (Anhalt \& Morris, 2008) compared with studies measuring peer or romantic attachment (Eng et al., 2001; McDermott et al., 2015) suggest that parental attachment may contribute less to adult social anxiety. Future research would benefit from prospective designs, especially those designed to test the role of mediators between attachment and social anxiety. Experience-sampling methods (Scollon, et al., 2009) which allow the exploration of moment-by-moment changes in social anxiety would also be beneficial here.

A further challenge to this area of literature is that overlap in the content of self-report attachment and social anxiety measures may exaggerate associations, since both measures 
may ask about themes such as discomfort or distrust in relationships. However, this possibility is unlikely to fully account for findings, since social anxiety measures often focus on behaviour and psychophysiology aspects of anxiety (e.g., arousal, blushing) in specific social settings, whilst attachment measures concern general patterns of relating (and associated cognitions) across inter-personal relationships. The impact of this overlap on the included literature is unclear, but has the potential to weaken or invalidate conclusions of much of the research in this area.

A number of further limitations of the included literature require mention. The variety of assessment measures used to operationalise both attachment and social anxiety likely contributed to variability in the findings. Greater consistency between research groups on choice of attachment measures would therefore be beneficial. Research has shown that selfreport and behavioural/observational measures of attachment are not highly correlated, suggesting they may be measuring separate constructs (Roisman et al., 2007; Ravitz et al., 2010). These two types of measures may explain unique variance in social anxiety and so could be used together in future research. Several studies used convenience samples of student populations, limiting the generalisability of findings. Though social anxiety can be conceptualised on a continuum with similar underlying processes at all levels (Ruscio, 2010), inclusion of greater clinical populations in future research in this area will allow for exploration of this conceptualisation and of attachment processes in people more significantly impaired. The overlap between social anxiety and depression was also not always well accounted for.

\section{Limitations}

The findings of this review must be understood in the context of several limitations. Reviews included were limited to studies published in English, and this could have excluded 
several relevant studies from other languages and cultures. Studies exploring social anxiety and attachment in late adolescents were not included, and may have altered conclusions. However, adolescence is an important time in terms of the development of social anxiety, and so probably warrants a separate review. Meta-analysis was inappropriate as different theoretical approaches to assessing attachment meant findings were too heterogeneous, but this also limited our ability to infer population effect sizes from identified studies.

\section{Clinical relevance}

In accordance with findings clinicians should consider attachment relationships and experiences as potential precursors of social anxiety, when engaging in assessment and formulation with clients. In particular, attachment could be understood as a potential contributor to anxiogenic thinking styles and behaviours indicated by models of social anxiety (i.e. Clark \& Wells, 1995; Gilbert, 2000). Self-protective attachment behaviours, such as avoidance, appear to result in withdrawal or social anxiety when maladaptively applied. Aiming to change such behaviours without attending to their origins in IWMs and attachment experiences may limit the efficacy of interventions. Additionally, identification of negative IWMs of self or other could trigger preventative interventions reducing social anxiety and the associated distress and economic burden. Greater consideration could also be given to reaching avoidant or fearfully attached groups, who naturally may limit social contact. There is preliminary evidence that psychotherapy can lead to improvements in attachment security (Taylor, et al., 2015), which may account in part for the beneficial effects of psychotherapy for those with social anxiety.

\section{Conclusion}

This is the first review of the literature exploring the relationship between adult attachment and social anxiety. It provides preliminary evidence that attachment insecurity, 
and particularly anxious attachment style, is positively associated with social anxiety.

However, there is a need for more robust and homogeneous research assessing longitudinal relationships between attachment and social anxiety, as well as potential mediators of this relationship. This remains a promising, but underdeveloped, area of research. 


\section{References}

Aderka, I.M., Weisman, O., Shahar, G., Gilboa-Schechtman, E., 2009. The roles of the social rank and attachment systems in social anxiety. Pers. Indiv. Differ. 47, 284-288. doi:10.1016/j.paid.2009.03.014

Aderka, I.M., Hofmann, S.G., Nickerson, A., Hermesh, H., Gilboa-Schechtman, E., Marom, S., 2012. Functional impairment in social anxiety disorder. J. Anxiety Disord., 26, 393-400. doi: 10.1016/j.janxdis.2012.01.003.

Ainsworth, M.D.S., Blehar, M.C., Waters, E., Wall, S., 1978. Patterns of attachment: A psychological study of the strange situation. Erlbaum, Hillsdale, NJ.

Anhalt, K., Morris, T.L., 2008. Parenting characteristics associated with anxiety and depression: A multivariate approach. J. Early Intensiv. Behav. Interv. 5, 122-137. DOI: http://dx.doi.org/10.1037/h0100427

Armsden, G.C., Greenberg, M.T., 1987. The inventory of parent and peer attachment: Individual differences and their relationship to psychological well-being in adolescence. J. Youth Adolesc. 16, 427-454. DOI: http://dx.doi.org/10.1007/BF02202939

Baumeister, R.F., Leary, M.R., 1995. The need to belong: desire for interpersonal attachments as a fundamental human motivation. Psychological bulletin. 117, 497-529. DOI: http://dx.doi.org/10.1037/0033-2909.117.3.497

Bartholomew, K., 1990. Avoidance of intimacy: An attachment perspective. J. Soc. Pers. Relation., 7,147-178. DOI: $10.1177 / 0265407590072001$

Bartholomew, K., Horowitz, L.M., 1991. Attachment styles among young adults: a test of a fourcategory model. J. Pers. Soc. Psychol. 61, 226-244. DOI: http://dx.doi.org/10.1037/00223514.61.2.226

Beesdo, K., Bittner, A., Pine, D.S., Stein, M.B., Höfler, M., Lieb, R., Wittchen, H.-U., 2007. Incidence of social anxiety disorder and the consistent risk for secondary depression in the 
first three decades of life. Arch. Gen. Psychiatry, 64, 903-912. doi: 10.1001/archpsyc.64.8.903.

Bifulco, A., Kwon, J., Jacobs, C., Moran, P.M., Bunn, A., Beer, N., 2006. Adult attachment style as mediator between childhood neglect/abuse and adult depression and anxiety. Soc. Psychiatry Psychiatr. Epidemiol. 41, 796-805. DOI: 10.1007/s00127-006-0101-z

Bifulco, A., Lillie, A., Ball, B., Moran, P., 1998. Attachment Style Interview (ASI) Training manual. Royal Holloway, University of London, London.

Boelen, P.A., Reijntjes, A., Carleton, R.N., 2014. Intolerance of Uncertainty and Adult Separation Anxiety. Cogn. Behav. Ther. 43, 133-144. DOI: 10.1080/16506073.2014.888755

Bohlin, G., Hagekull, B., 2009. Socio-emotional development: From infancy to young adulthood. Scand. J. Psychol. 50, 592-601. doi: 10.1111/j.1467-9450.2009.00787.x.

Bowlby, J., 1988. A secure base: Parent-child attachment and healthy human development. Routledge, London.

Boyce, P., Parker, G., 1989. Development of a scale to measure interpersonal sensitivity. Aust. N. Z. J. Psychiatry. 23, 341-351. DOI: http://dx.doi.org/10.3109/00048678909068291

Brennan, K.A., Clark, C.L. Shaver, P.R., 1998. Self-report measurement of adult attachment: An integrative overview, in: Simpson, J.A., Rholes, W.S. (Eds.) Attachment theory and close relationships. Guildford Press, New York, pp. 46-76.

Bretherton, I., Munholland, K.A., 1999. Internal working models in attachment relationships: A construct revisited, in: Cassidy, J., Shaver, P.R. (Eds.), Handbook of attachment: Theory, research and clinical applications, second ed. Guildford press, New York, pp. 102-127.

Brumariu, L.E., Kerns, K.A., 2008. Mother-child attachment and social anxiety symptoms in middle childhood. J. Appl. Dev. Psychol. 29, 393-402. doi: 10.1016/j.appdev.2008.06.002 
Brumariu, L.E., Obsuth, I., Lyons-Ruth, K., 2013. Quality of attachment relationships and peer relationship dysfunction among late adolescents with and without anxiety disorders. J. Anxiety Disord. 27, 116-124. doi: 10.1016/j.janxdis.2012.09.002

Clark, D.M., Wells, A., 1995. A cognitive model of social phobia, in: Heimberg, R.G., Liebowitz, M.R., Hope, D.A., Schneier, F.R. (Eds.), Social phobia: Diagnosis, assessment, and treatment. The Guildford Press, New York, pp.69-93.

Cohen, J., 1992. A power primer. Psychol. Bull. 112, 155-159. DOI: http://dx.doi.org/10.1037/00332909.112.1.155

Collins, N.L., 1996. Working models of attachment: Implications for explanation, emotion, and behavior. J. Pers. Soc. Psychol. 71, 810-832. DOI: http://dx.doi.org/10.1037/00223514.71.4.810

Collins, N.L., Read, S.J., 1990. Adult attachment, working models, and relationship quality in dating couples. J. Pers. Soc. Psychol. 58, 644-663. DOI: http://dx.doi.org/10.1037/00223514.58.4.644

Connor, K.M., Davidson, J.R., Churchill, L.E., Sherwood, A., Weisler, R.H., Foa, E., 2000. Psychometric properties of the Social Phobia Inventory (SPIN) New self-rating scale. Br. J. Psychiatry. 176, 379-386. DOI: http://dx.doi.org/10.1192/bjp.176.4.379

Copeland, W.E., Angold, A., Shanahan, L., Costello, E.J., 2014. Longitudinal patterns of anxiety from childhood to adulthood: the Great Smoky Mountains Study. J. Am. Acad. Child Adolesc. Psychiatry. 53, 21-33. doi:10.1016/j.jaac.2013.09.017

Cunha, M., Soares, I., Gouveia, J.P., 2008. The role of individual temperament, family and peers in social anxiety disorder: A controlled study. Int. J. Clin. Health Psychol. 8, 631-655.

Dağ, İ.G., Gülüm, İ.,V., 2013. The mediator role of cognitive features in the relationship between adult attachment patterns and psychopathology symptoms: Cognitive flexibility. Türk Psikiyatri Derg. 24, 240-247. 
Dakanalis, A., Timko, C.A., Favagrossa, L., Riva, G., Zanetti, M.A., Clerici, M., 2014. Why do only a minority of men report severe levels of eating disorder symptomatology, when so many report substantial body dissatisfaction? Examination of exacerbating factors. Eat. Disord. 22, 292-305. doi:10.1080/10640266.2014.898980

Darcy, K., Davila, J., Beck, J.G., 2005. Is social anxiety associated with both interpersonal avoidance and interpersonal dependence? Cogn. Ther. Res. 29, 171-186. doi:10.1007/s10608-005-31634

Davila, J. \& Beck, J. G. (2002). Is social anxiety associated with impairment in close relationships? A preliminary investigation. Behavior Therapy. 33, 427-446. DOI: http://dx.doi.org/10.1016/S0005-7894(02)80037-5

Davila, J. Sargent, E., 2003. The meaning of life (events) predicts change in attachment security. Pers. Soc. Psychol. Bull. 29, 1383-1395. doi: 10.1177/0146167203256374

Eng, W., Heimberg, R.G., Hart, T.A., Schneier, F.R., Liebowitz, M.R., 2001. Attachment in individuals with social anxiety disorder: the relationship among adult attachment styles, social anxiety, and depression. Emotion. 1, 365-380. DOI: http://dx.doi.org/10.1037/15283542.1.4.365

Erozkan, A. (2009). The relationship between attachment styles and social anxiety: An investigation with Turkish university students. Soc. Behav. Pers. 37, 835-844. doi:10.2224/sbp.2009.37.6.835

Fan, Q., Chang, W.C., 2015. Social Anxiety among Chinese People. ScientificWorldJournal, Article ID 743147, 1-12. doi:10.1155/2015/743147

Feeney, J.A., Noller, P., Hanrahan, M., 1994. Assessing adult attachment, in: Sperling, M.B., Berman, W.H. (Eds.) Attachment in adults: Clinical and developmental perspectives. Guildford Press, New York, pp. 128-152. 
Fehm, L., Pélissolo, A., Furmark, T. Wittchen, H.-U., 2005. Size and burden of social phobia in Europe. Eur. Neuropsychopharmacol., 15, 453-462. doi:10.1016/j.euroneuro.2005.04.002 Fenigstein, A., Scheier, M.F., Buss, A.H., 1975. Public and private self-consciousness: Assessment and theory. J. Consult. Clin. Psychol. 43, 522-527. DOI: http://dx.doi.org/10.1037/h0076760

First, M.B., Spitzer, R.L., Gibbon, M., Williams, J.B., 1995. Structured clinical interview for DSMIV axis I disorders-patient edition (SCID-I/P, Version 2.0). Biometrics Research Department, New York State Psychiatric Institute, New York.

Fortson, B.L., 2005. Risk and Resilience in Youth: An Examination of Moderating Factors (Ph.D. thesis). West Virginia University, USA.

Fraley, R.C., Roisman, G.I., Booth-LaForce, C., Owen, M.T., Holland, A.S., 2013. Interpersonal and Genetic Origins of Adult Attachment Styles: A Longitudinal Study from Infancy to Early Adulthood. J. Pers. Soc. Psychol. 104, 817-838. doi:10.1037/a0031435

Fraley, R.C., Waller, N.G., Brennan, K.A., 2000. An item response theory analysis of self-report measures of adult attachment. J. Pers. Soc. Psychol. 78, 350-365. DOI: http://dx.doi.org/10.1037/0022-3514.78.2.350

Gajwani, R., Patterson, P., Birchwood, M., 2013. Attachment: Developmental pathways to affective dysregulation in young people at ultra-high risk of developing psychosis. Br. J. Clin. Psychol. 52, 424-437. doi: 10.1111/bjc.12027

Gilbert, P., 2000. The relationship of shame, social anxiety and depression: The role of the evaluation of social rank. Clin. Psychol. Psychother. 7, 174-189. DOI: 10.1002/10990879(200007)7:3<174::AID-CPP236>3.0.CO;2-U

Greenwood, D.N., 2008. Television as escape from self: Psychological predictors of media involvement. Pers. Indiv. Differ. 44, 414-424. doi:10.1016/j.paid.2007.09.001 
Griffin, D.W., Bartholomew, K., 1994. Models of the self and other: Fundamental dimensions underlying measures of adult attachment. J. Pers. Soc. Psychol. 67, 430-445. DOI: http://dx.doi.org/10.1037/0022-3514.67.3.430

Gülüm, İ.V., Dağ, İ.G., 2014. The Mediator Role of the Cognitive Features in the Relationship between Adult Attachment Patterns and Psychopathology Symptoms: The Locus of Control and Repetitive Thinking. Türk Psikiyatri Derg. 25, 244-252.

Hazan, C., Shaver, P., 1987. Romantic love conceptualized as an attachment process. J. Pers. Soc. Psychol. 52, 511-524. DOI: http://dx.doi.org/10.1037/0022-3514.52.3.511

Henderson, L., Gilbert, P., Zimbardo, P., 2014. Shyness, social anxiety, and social phobia, in: Hofmann, S.G., DiBartolo, P.M. (Eds.), Social Anxiety: Clinical, Developmental, and Social Perspectives. Elsevier, London, pp. 95 - 115.

Hoyer, J., Wiltink, J., Hiller, W., Miller, R., Salzer, S., Sarnowsky, S., Stangier, U., Strauss, B., Willutzki, U., Leibing, E., 2016. Baseline patient characteristics predicting outcome and attrition in cognitive therapy for social phobia: Results from a large multicentre trial. Clin. Psychol. Psychother. 23, 35-46. doi:10.1002/cpp.1936

Jordan, N.A., 2010. This is why we play the game: A quantitative study of attachment style and social anxiety's impact on participation in online gaming relationships (Ph.D. thesis). Syracuse University. USA.

Kashdan, T.B., Roberts, J.E., 2011. Comorbid social anxiety disorder in clients with depressive disorders: Predicting changes in depressive symptoms, therapeutic relationships, and focus of attention in group treatment. Behav. Res. Ther. 49, 875-884. doi: 10.1016/j.brat.2011.10.002

Kessler, R.C., Avenevoli, S., McLaughlin, K.A., Green, J.G., Lakoma, M.D., Petukhova, M., Pine, D.S., Sampson, N.A., Zaslavsky, A.M., Merikangas, K.R., 2012. Lifetime comorbidity of DSM-IV disorders in the NCS-R Adolescent Supplement (NCS-A). Psychological Medicine, 42, 1997-2010. DOI: http://dx.doi.org/10.1017/S0033291712000025 
Kessler, R.C., Petukhova, M., Sampson, N.A., Zaslavsky, A.M., Wittchen, H.-U., 2012. Twelvemonth and lifetime prevalence and lifetime morbid risk of anxiety and mood disorders in the United States. Int. J. Methods Psychiatr. Res., 21, 169-184. doi: 10.1002/mpr.1359.

Leary, M.R., 1983a. A brief version of the Fear of Negative Evaluation Scale. Pers. Soc. Psychol. Bull. 9, 371-375. DOI: http://dx.doi.org/10.1177/0146167283093007

Leary, M.R., 1983b. Social anxiousness: The construct and its measurement. J. Pers. Assess. 47, 6675. DOI:10.1207/s15327752jpa4701_8

Liebowitz, M.R., 1987. Social phobia. Mod. Probl. Pharmacopsychiatry. 22, 141-173.

Lionberg, C.A., 2003. Characteristics and quality of personal relationships in generalized social phobia (Ph.D. thesis). University of Manitoba, Canada.

Locke, B.D., Buzolitz, J.S., Lei, P.W., Boswell, J.F., McAleavey, A.A., Sevig, T.D., Dowis, J.D., Hayes, J.A., 2011. Development of the Counseling Center Assessment of Psychological Symptoms-62 (CCAPS-62). J. Couns. Psychol. 58, 97-109. doi: 10.1037/a0021282.

Marks, I.M., Mathews, A.M., 1979. Brief standard self-rating for phobic patients. Behav. Res. Ther. 17, 263-267. DOI: http://dx.doi.org/10.1016/0005-7967(79)90041-X

Mattick, R.P., Clarke, J.C., 1998. Development and validation of measures of social phobia scrutiny fear and social interaction anxiety. Behav. Res. Ther. 36, 455-470. doi: 10.1016/S00057967(97)10031-6

Main, M., Goldwyn, R., Hesse, E. 2003. Adult attachment scoring and classification system (version 7.2). Unpublished manuscript, University of California, Berkeley.

Mayo-Wilson, E., Dias, S., Mavranezouli, I., Kew, K., Clark, D.M., Ades, A.E., Pilling, S., 2014. Psychological and pharmacological interventions for social anxiety disorder in adults: a systematic review and network meta-analysis. Lancet Psychiatry. 1, 368-376. DOI: http://dx.doi.org/10.1016/S2215-0366(14)70329-3 
McDermott, R.C., Cheng, H.L., Wright, C., Browning, B.R., Upton, A.W., Sevig, T.D., 2015. Adult Attachment Dimensions and College Student Distress The Mediating Role of Hope. Counsel. Psychol. 43, 822-852. doi:10.1177/0011000015575394

Michail, M., Birchwood, M., 2014. Social anxiety in first-episode psychosis: the role of childhood trauma and adult attachment. J. Affect. Disord. 163, 102-109. doi:10.1016/j.jad.2014.03.033

Mickelson, K.D., Kessler, R.C., Shaver, P.R., 1997. Adult attachment in a nationally representative sample. J. Pers. Soc. Psychol. 73, 1092-1106. doi:10.1037/0022-3514.73.5.1092

NICE, 2013. Social anxiety disorder: recognition, assessment and treatment (CG 159). NICE, London.

Nikitin, J., Freund, A.M., 2010. When wanting and fearing go together: The effect of co-occurring social approach and avoidance motivation on behavior, affect, and cognition. Eur. J. Soc. Psychol.40, 783-804. DOI: 10.1002/ejsp.650

Ollendick, T.H., Benoit, K.E., 2012. A parent-child interactional model of social anxiety disorder in youth. Clin. Child Fam. Psychol. Rev. 15, 81-91. DOI: 10.1007/s10567-011-0108-1

Özbay, Y., Palanci, M., 2001. The validity and reliability of social anxiety scale for university students, In: 6th National Congress on Psychological Counseling and Guidance, METU, Ankara, Turkey.

Parade, S.H., Leerkes, E.M., Blankson, A.N., 2010. Attachment to parents, social anxiety, and close relationships of female students over the transition to college. J. Youth Adolesc. 39, 127-137. doi:10.1007/s10964-009-9396-X

Parker, G., Tupling, H., Brown, L.B., 1979. A parental bonding instrument. Br. J. Med. Psychol. 52, 1-10. DOI: http://dx.doi.org/10.1111/j.2044-8341.1979.tb02487.x

Pierce T., Lydon J., 2001. Global and specific relational models in the experience of social interactions. J. Pers. Soc. Psychol., 80, 613-631. DOI: http://dx.doi.org/10.1037/00223514.80.4.613 
Ravitz, P., Maunder, R., Hunter, J., Sthankiya, B., Lancee, W., 2010. Adult attachment measures: A 25-year review. J. Psychosom. Res. 69, 419-432. DOI: http://dx.doi.org/10.1016/j.jpsychores.2009.08.006

Roisman, G.I., Holland, A., Fortuna, K., Fraley, R.C., Clausell, E., Clarke, A., 2007. The Adult Attachment Interview and self-reports of attachment style: an empirical rapprochement. J. Pers. Soc. Psychol. 92, 678-697. DOI: http://dx.doi.org/10.1037/0022-3514.92.4.678

Roring, S.A., 2008. The relationships among adult attachment style, perceived social support, and social anxiety in college students (Masters thesis). Oklahoma State University, USA

Ruscio, A.M., 2010. The latent structure of social anxiety disorder: Consequences of shifting to a dimensional diagnosis. J. Abnorm. Psychol. 119, 662-671. doi: 10.1037/a0019341

Scollon, C.N., Prieto, C.K., Diener, E., 2009. Experience sampling: promises and pitfalls, strength and weaknesses, in: Diener, E. (Ed.) Assessing well-being. Springer, London, pp. 157-180.

Shi, L., Wampler, R., Wampler, K., 2013. A comparison of self-report adult attachment measures: How do they converge and diverge. Univ. J. Psychol. 1, 10-19. doi: 10.13189/ujp.2013.010102.

Sparrevohn, R.M., Rapee, R.M., 2009. Self-disclosure, emotional expression and intimacy within romantic relationships of people with social phobia. Behav. Res. Ther. 47, 1074-1078. doi:10.1016/j.brat.2009.07.016

Stein, M.B., Fuetsch, M., Müller, N., Höfler, M., Lieb, R., Wittchen, H.-U., 2001. Social anxiety disorder and the risk of depression: a prospective community study of adolescents and young adults. Arch. Gen. Psychiatry. 58, 251-256. DOI: http://dx.doi.org/10.1001/archpsyc.58.3.251

Taylor, P.J., Hutton, P., Wood, L. 2014. Are people at risk of psychosis also at risk of suicide and self-harm? A systematic review and meta-analysis. Psychol. Med. 45, 911-926. doi: $10.1017 / \mathrm{S} 0033291714002074$ 
Taylor, P.J., Rietzschel, J., Danquah, A., Berry, K., 2015. Changes in attachment representations during psychological therapy. Psychother. Res. 25, 222-238. doi: $10.1080 / 10503307.2014 .886791$

Turner, S.M., Beidel, D.C., Dancu, C.V., Stanley, M.A., 1989. An empirically derived inventory to measure social fears and anxiety: the Social Phobia and Anxiety Inventory. Psychol. Assess. 1, 35-40. DOI: http://dx.doi.org/10.1037/1040-3590.1.1.35

Van Buren, A., Cooley, E.L., 2002. Attachment styles, view of self and negative affect. N. Am. J. Psychol. 4, 417-430.

Vertue, F.M., 2003. From adaptive emotion to dysfunction: An attachment perspective on social anxiety disorder. Pers. Soc. Psychol. Rev. 7, 170-191. doi: 10.1207/S15327957PSPR0702_170-191

Wei, M., Russell, D.W., Mallinckrodt, B., Vogel, D.L., 2007. The Experiences in Close Relationship Scale (ECR)-short form: Reliability, validity, and factor structure. J. Pers. Assess. 88, 187204. DOI:10.1080/00223890701268041

Weisman, O., Aderka, I.M., Marom, S., Hermesh, H., Gilboa-Schechtman, E., 2011. Social rank and affiliation in social anxiety disorder. Behav. Res. Ther. 49, 399-405. doi: 10.1016/j.brat.2011.03.010

Williams, J.W., Plassman, B.L., Burke, J., Holsinger, T., Benjamin, S., 2010. Preventing alzheimer's disease and cognitive decline. Evidence report/technology assessment No. 193. (Prepared by the duke evidence-based practice center under contract No. HHSA 290-2007-10066-I). Agency for Healthcare Research and Quality, Rockville, MD.

Wittchen, H.-U. Jacobi, F., 2005. Size and burden of mental disorders in Europe-a critical review and appraisal of 27 studies. Eur. Neuropsychopharmacol. 15, 357-376. DOI: http://dx.doi.org/10.1016/j.euroneuro.2005.04.012 
World Health Organization, 1990. Composite International Diagnostic Interview. World Health Organization, Geneva, Switzerland. 


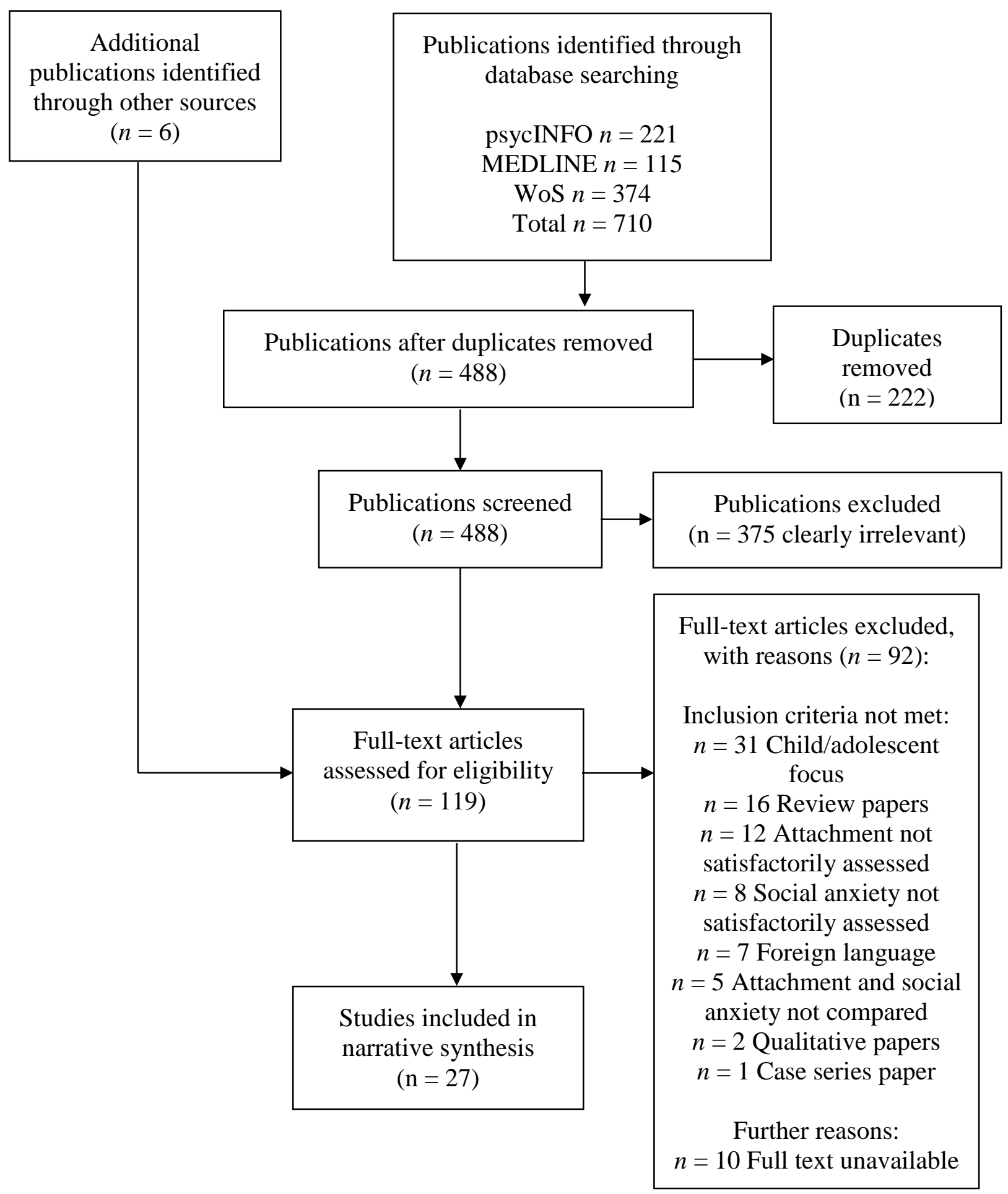

Figure 1. Literature Review search flow diagram 
Table 1

Characteristics of Included Studies

\begin{tabular}{|c|c|c|c|c|c|c|}
\hline $\begin{array}{l}\text { Authors, year and } \\
\text { country }\end{array}$ & Design & Sample source & Sample characteristics & $\begin{array}{l}\text { control group } \\
\text { characteristics }\end{array}$ & $\begin{array}{l}\text { Attachment } \\
\text { Measure }\end{array}$ & $\begin{array}{l}\text { Social anxiety } \\
\text { Measure }\end{array}$ \\
\hline $\begin{array}{l}\text { Aderka et al. } \\
(2009), \text { Israel }\end{array}$ & $\begin{array}{l}\text { Cross- } \\
\text { sectional }\end{array}$ & $\begin{array}{l}\text { Community } \\
\text { snowball } \\
\text { recruitment }\end{array}$ & $\begin{array}{l}\mathrm{n}=102(72 \text { female }) \\
\text { Age } \mathrm{M}=29.5(\mathrm{SD}= \\
9.0) ; \text { ethnicity not } \\
\text { stated }\end{array}$ & - & ECR & LSAS \\
\hline $\begin{array}{l}\text { Anhalt \& Morris } \\
\text { (2008), USA }\end{array}$ & $\begin{array}{l}\text { Cross- } \\
\text { sectional }\end{array}$ & Students & $\begin{array}{l}\mathrm{n}=434(282 \text { female); } \\
\text { Age } \mathrm{M}=19.10(\mathrm{SD}= \\
\text { 1.05); Ethnicity: } 92 \% \\
\text { caucasian; } 4 \% \\
\text { African-American; } 2 \% \\
\text { Asian-American; } 1 \% \\
\text { Hispanic; } 2 \% \text { other }\end{array}$ & - & PBI; IPPA & SPAI \\
\hline $\begin{array}{l}\text { Bifulco et al. } \\
\text { (2006), UK }\end{array}$ & Longitudinal & Community & $\begin{array}{l}\mathrm{n}=154 \text { (154 female); } \\
\text { Age range } 26-59 ; \\
\text { ethnicity not stated }\end{array}$ & - & ASI & SCID \\
\hline $\begin{array}{l}\text { Boelen, et al. } \\
\text { (2014), The } \\
\text { Netherlands }\end{array}$ & $\begin{array}{l}\text { Cross- } \\
\text { sectional }\end{array}$ & Students & $\begin{array}{l}\mathrm{n}=215(198 \text { female }) \\
\text { Age } \mathrm{M}=21.6(\mathrm{SD}= \\
2.0) ; \text { ethnicity not } \\
\text { stated }\end{array}$ & - & ECR-R & SPIN \\
\hline $\begin{array}{l}\text { Bohlin \& } \\
\text { Hagekull (2009), } \\
\text { Sweden }\end{array}$ & Longitudinal & $\begin{array}{l}\text { cohort born in } \\
\text { during } 11 \\
\text { week period, } \\
1985\end{array}$ & $\begin{array}{l}\mathrm{n}=85 \text { (Gender not } \\
\text { stated); Age } \mathrm{M}=21 \\
\text { and } 3 \text { months }(\mathrm{SD}=3 \\
\text { months); ethnicity not } \\
\text { stated }\end{array}$ & - & $\begin{array}{l}\text { Stange situation } \\
\text { (Ainsworth et } \\
\text { al., 1978) at } 15 \\
\text { months }\end{array}$ & SIAS \& SPS \\
\hline
\end{tabular}




\begin{tabular}{|c|c|c|c|c|c|c|}
\hline $\begin{array}{l}\text { Dă̆, \& Gülüm } \\
\text { (2013), Turkey }\end{array}$ & $\begin{array}{l}\text { Cross- } \\
\text { sectional }\end{array}$ & Students & $\begin{array}{l}\mathrm{n}=992(661 \text { female }) \\
\text { Age } \mathrm{M}=21.07(\mathrm{SD}= \\
2.22) ; \text { ethnicity not } \\
\text { stated }\end{array}$ & - & ECR-R & $\overline{\text { LSAS }}$ \\
\hline $\begin{array}{l}\text { Dakanalis et al., } \\
\text { (2014), Italy }\end{array}$ & $\begin{array}{l}\text { Cross- } \\
\text { sectional }\end{array}$ & $\begin{array}{l}\text { Students at } \\
\text { three } \\
\text { universities in } \\
\text { Italy }\end{array}$ & $\begin{array}{l}\mathrm{n}=359(0 \text { female }) \\
\text { Age } \mathrm{M}=20.4(\mathrm{SD}= \\
\text { 3.3); ethnicity not } \\
\text { stated }\end{array}$ & - & $\begin{array}{l}\text { Italian validated } \\
\text { ASQ (Fossati et } \\
\text { al., 2003) }\end{array}$ & $\begin{array}{l}\text { Italian validated } \\
\text { Interaction } \\
\text { Anxiousness } \\
\text { Scale (Conti, } \\
\text { 1999) } \\
\end{array}$ \\
\hline $\begin{array}{l}\text { Darcy, et al. } \\
\text { (2005), USA }\end{array}$ & $\begin{array}{l}\text { Cross- } \\
\text { sectional }\end{array}$ & Students & $\begin{array}{l}\mathrm{n}=168(88 \text { female }) ; \\
\text { Age } \mathrm{M}=18.72(\mathrm{SD}= \\
\text { 1.05); Ethnicity: } \\
73.5 \% \text { Caucasian; } 9 \% \\
\text { African American; } 8 \% \\
\text { Asian Pacific Islander; } \\
\text { 4\% Latino/a; 6\% other }\end{array}$ & - & RQ & $\overline{\text { SPAI }}$ \\
\hline $\begin{array}{l}\text { Eng et al., (2001), } \\
\text { USA }\end{array}$ & $\begin{array}{l}\text { Controlled } \\
\text { cross- } \\
\text { sectional }\end{array}$ & $\begin{array}{l}\text { population } \\
\text { seeking } \\
\text { anxiety } \\
\text { treatment }\end{array}$ & $\begin{array}{l}\text { Primary sample } \mathrm{n}= \\
118 \text { (47 female); Age } \\
\mathrm{M}=32.73 \text { (SD = } \\
\text { 10.13); Ethnicity: } \\
\text { 78.4\% Caucasian, } \\
\text { 12.9\% African } \\
\text { American, 8.6\% other; } \\
\text { Replication sample } \mathrm{n}= \\
56 \text { (23 female); Age M } \\
=33.39 \text { (SD = 9.04); } \\
\text { Ethnicity: 39.3\% } \\
\text { Caucasian, 25.0\% } \\
\text { African American, } \\
\text { 35.7\% other }\end{array}$ & $\begin{array}{l}\mathrm{n}=36(17 \text { female }) \\
\text { Age } \mathrm{M}=32.66(\mathrm{SD}= \\
\text { 10.68); Ethnicity: } \\
\text { 61.1\% Caucasian, } \\
27.8 \% \text { African } \\
\text { American, } 11.1 \% \text { other }\end{array}$ & RAAS & $\begin{array}{l}\text { LSAS-total fear } \\
\text { scale; SIAS \& } \\
\text { SPS; FQ-social; } \\
\text { BFNE; IPSM }\end{array}$ \\
\hline
\end{tabular}




\begin{tabular}{|c|c|c|c|c|c|c|}
\hline $\begin{array}{l}\text { Erozkan (2009), } \\
\text { Turkey }\end{array}$ & $\begin{array}{l}\text { Cross- } \\
\text { sectional }\end{array}$ & Students & $\begin{array}{l}\mathrm{n}=600(300 \text { female }) \\
\text { Age } \mathrm{M}=21.80(\mathrm{SD}= \\
2.20) ; \text { ethnicity not } \\
\text { stated }\end{array}$ & - & RSQ & SAS \\
\hline $\begin{array}{l}\text { Fan \& Chang } \\
\text { (2015) (study 2), } \\
\text { China }\end{array}$ & $\begin{array}{l}\text { Cross- } \\
\text { sectional }\end{array}$ & Students & $\begin{array}{l}\mathrm{n}=296(95 \text { female }) \\
\text { Age } \mathrm{M}=20.78(\mathrm{SD}= \\
1.73) ; \text { Ethnicity: } 100 \% \\
\text { Chinese }\end{array}$ & - & ECR-R & $\begin{array}{l}\text { SIAS \& SPS } \\
\text { plus } 10 \text { new } \\
\text { items specific to } \\
\text { Chinese } \\
\text { population (Fan } \\
\text { \& Chang, 2015) }\end{array}$ \\
\hline $\begin{array}{l}\text { Forston (2005), } \\
\text { USA }\end{array}$ & $\begin{array}{l}\text { Cross- } \\
\text { sectional }\end{array}$ & $\begin{array}{l}\text { Students } \\
\text { (Psychology } \\
\text { undergratuates } \\
\text { only }\end{array}$ & $\begin{array}{l}\mathrm{n}=503(358 \text { female }) \\
\text { Age } \mathrm{M}=19.9(\mathrm{SD}= \\
\text { 2.8); Ethnicity: } 89.2 \% \\
\text { Caucasian; } 4.2 \% \\
\text { African American; } \\
\text { 1.6\% Asian/Pacific } \\
\text { Islander; } 1 \% \text { Hispanic; } \\
\text { 3.6\% Other }\end{array}$ & - & ASQ & SPAI \\
\hline $\begin{array}{l}\text { Gajwani, et al. } \\
\text { (2013), UK }\end{array}$ & $\begin{array}{l}\text { Cross- } \\
\text { sectional }\end{array}$ & $\begin{array}{l}\text { recruited from } \\
\text { EIS }\end{array}$ & $\begin{array}{l}\mathrm{n}=51(18 \text { female }) \\
\text { Age } \mathrm{M}=19(\mathrm{SD}= \\
\text { 3.09); Ethnicity: } \\
\text { 57\%White British; } \\
\text { 31\%Asian; } \\
\text { 4\%Black/Black British } \\
\text { Caribbean; } 2 \% \\
\text { Black/Black British } \\
\text { African; } 6 \% \text { other }\end{array}$ & - & RAAS & SIAS \& SPS \\
\hline $\begin{array}{l}\text { Greenwood } \\
\text { (2008), USA }\end{array}$ & $\begin{array}{l}\text { Cross- } \\
\text { sectional }\end{array}$ & Students & $\begin{array}{l}\mathrm{n}=241(191 \text { female }) ; \\
\text { Age and ethnicity not } \\
\text { stated }\end{array}$ & - & ECR & $\begin{array}{l}\text { subscale from } \\
\text { the MPPS-C }\end{array}$ \\
\hline
\end{tabular}




\begin{tabular}{|c|c|c|c|c|c|c|}
\hline $\begin{array}{l}\text { Gülüm \& Dă̆ } \\
\text { (2013) study 1, } \\
\text { Turkey }\end{array}$ & $\begin{array}{l}\text { Cross- } \\
\text { sectional }\end{array}$ & Students & $\begin{array}{l}\mathrm{n}=992(661 \text { female }) \\
\text { Age } M=21.07(\mathrm{SD}= \\
2.22)\end{array}$ & - & ECR-R & LSAS \\
\hline $\begin{array}{l}\text { Gülüm \& Dağ } \\
\text { (2013) study 2, } \\
\text { Turkey }\end{array}$ & $\begin{array}{l}\text { Cross- } \\
\text { sectional }\end{array}$ & Students & $\begin{array}{l}\mathrm{n}=875 \text { (581 female); } \\
\text { Age } \mathrm{M}=21.1(\mathrm{SD}= \\
1.90)\end{array}$ & - & ECR-R & LSAS \\
\hline $\begin{array}{l}\text { Hoyer et al. } \\
\text { (2016), Germany }\end{array}$ & $\begin{array}{l}\text { Cross- } \\
\text { sectional }\end{array}$ & $\begin{array}{l}\text { Community } \\
\text { Outpatients }\end{array}$ & $\begin{array}{l}\mathrm{n}=165-183(91-101 \\
\text { female }) ; \text { Age } \mathrm{M}= \\
34.94(\mathrm{SD}=12.11) ; \\
\text { Ethinicity not stated }\end{array}$ & - & $\begin{array}{l}\text { ECR-R (German } \\
\text { Version) }\end{array}$ & LSAS \\
\hline $\begin{array}{l}\text { Jordan (2010), } \\
\text { USA/International } \\
\text { (online } \\
\text { recruitment) }\end{array}$ & $\begin{array}{l}\text { Cross- } \\
\text { sectional }\end{array}$ & $\begin{array}{l}\text { users of online } \\
\text { gamer forums }\end{array}$ & $\begin{array}{l}\mathrm{n}=141(27 \text { female }) \\
\text { Age }=78 \%=18-24 ; \\
\text { 19.1\%=25-35; } \\
2.8 \%=36-45 ; 0 \%=45+; \\
\text { Ethnicity: } 75.9 \% \\
\text { Caucasian; } 9.9 \% \\
\text { Latino/Hispanic; } 7.1 \% \\
\text { Asian; } 2.8 \% \text { Biracial; } \\
\text { 1.4\% African } \\
\text { American; } 1.4 \% \\
\text { Native American; } \\
1.4 \% \text { other }\end{array}$ & - & RSQ & LSAS \\
\hline
\end{tabular}




\begin{tabular}{llll}
\hline Kashdan \& & Cross- & Community & $\mathrm{n}=76(59$ female); \\
Roberts, (2011), & sectional & Outpatients at & Age $\mathrm{M}=37.8(\mathrm{SD}=$ \\
USA & & a depression & $10.4) ;$ Ethnicity: \\
& & clinic & 89.5\% Caucasian; \\
& & $10.5 \%$ Other
\end{tabular}

Adapted ECR to SCID \& SIAS

assess state

attachment to

therapists \&

group; good

internal

consistency

\begin{tabular}{|c|c|c|c|c|c|c|}
\hline $\begin{array}{l}\text { Lionberg (2003) } \\
\text { study 1, Canada }\end{array}$ & $\begin{array}{l}\text { Controlled } \\
\text { cross- } \\
\text { sectional }\end{array}$ & $\begin{array}{l}\text { community } \\
\text { anxiety clinic; } \\
\text { control group } \\
\text { from local } \\
\text { community }\end{array}$ & $\begin{array}{l}\mathrm{n}=71(36 \text { female }) \\
\text { Age } \mathrm{M}=37.70(\mathrm{SD}= \\
12.33) ; \text { ethnicity not } \\
\text { stated }\end{array}$ & $\begin{array}{l}\text { Panic disorder group n } \\
=25(80 \% \text { female }) ; \\
\text { Age not reported; } \\
\text { Ethnicity not reported; } \\
\text { Healthy control } \mathrm{n}=46 \\
(59 \% \text { female }) ; \text { Age } \mathrm{M} \\
=37.30(\mathrm{SD}=12.28) ;\end{array}$ & RAAS & SCID \\
\hline $\begin{array}{l}\text { McDermott et al., } \\
\text { (2015), USA }\end{array}$ & $\begin{array}{l}\text { Cross- } \\
\text { sectional }\end{array}$ & Students & $\begin{array}{l}\mathrm{n}=2644(1216 \\
\text { female); Age } \mathrm{M}=22.5 \\
(\mathrm{SD}=5.26) ; \text { Ethnicity: } \\
67 \% \text { white; } 18 \% \\
\text { Asian/Asian } \\
\text { American; } 3.4 \% \text { multi- } \\
\text { racial; 3\% African } \\
\text { American/Blank; } 2.5 \% \\
\text { Latino/a; } 0.03 \% \\
\text { Pacific Islander }\end{array}$ & - & ECR-S & $\begin{array}{l}\text { Social anxiety } \\
\text { subscale of the } \\
\text { CCAPS-62 }\end{array}$ \\
\hline
\end{tabular}




\begin{tabular}{|c|c|c|c|c|c|c|}
\hline $\begin{array}{l}\text { Michail \& } \\
\text { Birchwood } \\
\text { (2014), UK }\end{array}$ & $\begin{array}{l}\text { Controlled } \\
\text { cross- } \\
\text { sectional }\end{array}$ & $\begin{array}{l}\text { Psychosis } \\
\text { groups: } \\
\text { service users } \\
\text { of } \\
\text { Birmingham } \\
\text { EIS; SAD } \\
\text { group: } \\
\text { respondents } \\
\text { from Social } \\
\text { Anxiety UK; } \\
\text { community } \\
\text { sample from } \\
\text { community }\end{array}$ & $\begin{array}{l}\text { Group 1: } \mathrm{n}=31(20 \\
\text { female) social anxiety } \\
\text { only; Age } \mathrm{M}=27.6 \\
(\mathrm{SD}=5.0) ; \text { Ethnicity = } \\
\text { 93.5\% White British, } \\
3.2 \% \text { Asian, 3.2\% } \\
\text { Black British, 0\% } \\
\text { Afro-Caribbean, 0\% } \\
\text { Other; Group 2: } \mathrm{n}=20 \\
\text { (13 female) first } \\
\text { episode psychosis with } \\
\text { social anxiety, Age M } \\
=24.4 \text { (SD = 5.1), } \\
\text { Ethnicity = 35\% White } \\
\text { British, 40\% Asian, } \\
\text { 10\% Black British, } \\
\text { 10\% Afro-Caribbean, } \\
5 \% \text { Other }\end{array}$ & $\begin{array}{l}\text { Group 3: } 60 \text { (14 } \\
\text { female) first episode of } \\
\text { psychosis without } \\
\text { social anxiety, Age M } \\
=24 \text { (SD = 4.5), } \\
\text { ethnicity = 18.3\% } \\
\text { White British, 50\% } \\
\text { Asian, 16.6\% Black } \\
\text { British, 15\% Afro- } \\
\text { Caribbean, 0\% Other; } \\
\text { Group 4: } \mathrm{n}=24 \text { (13 } \\
\text { female) healthy } \\
\text { community, Age M = } \\
24.2(\mathrm{SD}=5.0) \text {, } \\
\text { Ethinicity = 41.7\% } \\
\text { White British, 54.1\% } \\
\text { Asian, 0\% Black } \\
\text { British, 4.2\% Afro- } \\
\text { Caribbean, 0\% Other }\end{array}$ & RAAS & SIAS \& SPS \\
\hline $\begin{array}{l}\text { Mickelson, et al. } \\
\text { (1997), USA }\end{array}$ & $\begin{array}{l}\text { Cross- } \\
\text { sectional }\end{array}$ & $\begin{array}{l}\text { Data from the } \\
\text { national } \\
\text { comorbidity } \\
\text { survery } \\
\text { (household } \\
\text { survey of } \\
\text { population } \\
\text { between 15- } \\
54 \text { in US) }\end{array}$ & $\begin{array}{l}\mathrm{n}=8080(4083 \\
\text { female); Age: } 15-24 \\
\text { range }(\mathrm{n}=2000 ; \\
24.8 \% \text { of sample) } 25- \\
34 \text { range }(\mathrm{n}=2435 ; \\
30.1 \% \text { of sample) } 35- \\
44 \text { range }(\mathrm{n}=2189 ; \\
27.1 \% \text { of sample }) 45- \\
54 \text { range }(\mathrm{n}=1456 ; \\
18.0 \% \text { of sample); } \\
\text { Ethnicity }=75.3 \% \\
\text { Caucasian: } 11.5 \%\end{array}$ & - & $\begin{array}{l}\text { Attachment style } \\
\text { measure drawn } \\
\text { from Hazan \& } \\
\text { Shaver (1987) }\end{array}$ & CIDI \\
\hline
\end{tabular}


Black; 9.7\% Hispanic;

$3.5 \%$ other

\begin{tabular}{|c|c|c|c|c|c|c|}
\hline $\begin{array}{l}\text { Nikitin \& Freund } \\
\text { (2010) study } 1 \text {, } \\
\text { Switzerland }\end{array}$ & $\begin{array}{l}\text { Cross- } \\
\text { sectional }\end{array}$ & $\begin{array}{l}\text { Students and } \\
\text { community of } \\
\text { Zurich }\end{array}$ & $\begin{array}{l}\mathrm{n}=245(181 \text { female }) \\
\text { Age } \mathrm{M}=26.06(\mathrm{SD}= \\
5.95) ; \text { ethnicity not } \\
\text { stated }\end{array}$ & - & $\begin{array}{l}\text { ASQ, german } \\
\text { version (Hexel, } \\
\text { 2004) } \\
\text { abbreviated to } 18 \\
\text { marker items }\end{array}$ & SIAS only \\
\hline $\begin{array}{l}\text { Parade, et al. } \\
\text { (2010), USA }\end{array}$ & Longitudinal & Students & $\begin{array}{l}\mathrm{n}=172(172 \text { female }) \\
\text { Age } \mathrm{M}=18.09(\mathrm{SD}= \\
0.33) ; \text { Ethnicity }=70 \% \\
\text { white; } 18 \% \text { Black; } 5 \% \\
\text { Asian-American; } 3 \% \\
\text { Hispanic-non-white; } \\
\text { 4\% other }\end{array}$ & - & IPPA & SIAS only \\
\hline $\begin{array}{l}\text { Roring (2008), } \\
\text { USA }\end{array}$ & $\begin{array}{l}\text { Cross- } \\
\text { sectional }\end{array}$ & Students & $\begin{array}{l}\mathrm{n}=194(139 \text { female }) \\
\text { Age } \mathrm{M}=19.41(\mathrm{SD}= \\
\text { 1.39); Ethnicity: } \\
\text { 78.8\% Caucasian; } \\
\text { 3.6\% African } \\
\text { American; } 3.1 \% \text { Asian } \\
\text { American; } 2.6 \% \\
\text { Hispanic; } 4.6 \% \text { Native } \\
\text { American; } 6.2 \% \\
\text { Biracial; } 0.5 \% \\
\text { multiracial; } 0.5 \% \\
\text { Other }\end{array}$ & - & $\begin{array}{l}\text { Adapted RQ for } \\
\text { non-romantic } \\
\text { attachment }\end{array}$ & SIAS \& SPS \\
\hline $\begin{array}{l}\text { van Buren \& } \\
\text { Cooley (2002), } \\
\text { USA }\end{array}$ & $\begin{array}{l}\text { Cross- } \\
\text { sectional }\end{array}$ & Students & $\begin{array}{l}\mathrm{n}=123 \text { (Gender } \\
\text { unclear); Age unclear; } \\
\text { Ethnicity not stated. }\end{array}$ & - & RQ & IAS \\
\hline
\end{tabular}




\begin{tabular}{|c|c|c|c|c|c|c|}
\hline $\begin{array}{l}\text { Weisman et al. } \\
\text { (2011) study } 1 \text {, } \\
\text { Israel }\end{array}$ & $\begin{array}{l}\text { Controlled } \\
\text { cross- } \\
\text { sectional }\end{array}$ & $\begin{array}{l}\text { SAD } \\
\text { treatment } \\
\text { seekers \& } \\
\text { community } \\
\text { controls }\end{array}$ & $\begin{array}{l}\mathrm{n}=42(23 \text { female }) \\
\text { Age } \mathrm{M}=30.5(\mathrm{SD}= \\
6.2) ; \text { Ethnicity not } \\
\text { stated }\end{array}$ & $\begin{array}{l}\mathrm{n}=47(29 \text { female }) \\
\text { Age } \mathrm{M}=29.5(\mathrm{SD}= \\
\text { 8.9); Ethnicity not } \\
\text { stated }\end{array}$ & ECR & LSAS \\
\hline $\begin{array}{l}\text { Weisman et al. } \\
\text { (2011) study 2, } \\
\text { Israel }\end{array}$ & $\begin{array}{l}\text { Controlled } \\
\text { cross- } \\
\text { sectional }\end{array}$ & $\begin{array}{l}\text { SAD } \\
\text { treatment } \\
\text { seekers (with } \\
\text { MDD) group } \\
\text { \& other ANX } \\
\text { treatment } \\
\text { seekers with } \\
\text { MDD group }\end{array}$ & $\begin{array}{l}\mathrm{n}=45(18 \text { female }) \\
\text { people diagnosed with } \\
\mathrm{SAD} \text { and } \mathrm{MDD} ; \text { Age } \\
\mathrm{M}=28.6(\mathrm{SD}=5.7) ; \\
\text { Ethnicity not stated }\end{array}$ & $\begin{array}{l}\mathrm{n}=31 \text { (16 female) } \\
\text { people diagnosed with } \\
\text { anxiety disorders other } \\
\text { than } \mathrm{SAD} \text {, plus MDD; } \\
\text { Age } \mathrm{M}=33.7 \text { (SD = } \\
11.2) \text {; ethnicity not } \\
\text { stated }\end{array}$ & ECR & LSAS \\
\hline $\begin{array}{l}\text { Weisman, et al., } \\
\text { (2011) SEM, } \\
\text { Israel }\end{array}$ & $\begin{array}{l}\text { Controlled } \\
\text { cross- } \\
\text { sectional }\end{array}$ & $\begin{array}{l}\text { SAD } \\
\text { treatment } \\
\text { seekers }\end{array}$ & $\begin{array}{l}\mathrm{n}=87(41 \text { female }) \\
\text { people meeting } \mathrm{SAD} \\
\text { diagnostic criteria; } \\
\text { Age } \mathrm{M}=29.5(\mathrm{SD}= \\
6.0) ; \text { Ethnicity not } \\
\text { stated }\end{array}$ & - & ECR & LSAS \\
\hline
\end{tabular}

NOTE: ${ }^{1}$ demographic information unclear as a subset of participants was used for attachment and social anxiety comparison; Attachment assessments: ASI = Attachment Style Interview (Bifulco, et al., 1998); ASQ = Attachment Style Questionnaire (Feeney, et al., 1994); ECR = Experiences in Close Relationships Scale (Brennan, et al., 1998); ECR-R = Experiences in Close Relationships Scale-Revised (Fraley, et al., 2000); ECR-S = Experiences in Close Relationships Scale - Short form (Wei, et al., 2007); IPPA = Inventory of Parent and Peer Attachment (Armsden \& Greenberg, 1987); RAAS = Revised Adult Attachment Scale (Collins \& Read, 1990; Collins, 1996); RQ = Relationship Questionnaire (Bartholomew \& Horowitz, 1991); RSQ = Relationship Scales Questionnaire (Griffin \& Bartholomew, 1994). Social anxiety assessments: BFNE = Brief Fear of Negative Evaluation scale (Leary, 1983a); FQ-social = Fear Questionnaire-Social subscale (Marks \& Matthews, 1979); IAS = Interaction Anxiety Scale (Leary, 1983b); IPSM = Interpersonal Sensitivity Measure (Boyce \& Parker, 1989); LSAS = Liebowitz Social Anxiety Scale (Liebowitz, 1987); MPPS-C = Measure of Public and Private Self-Consciousness (Fenigstein, et al., 1975); PBI = Parental Bonding Instrument (Parker, et al., 1979); SAS = Social Anxiety Scale (Özbay \& Palanci, 2001); SIAS = Social Interaction Anxiety Scale (Mattick \& Clarke, 1998; NOTE: companion measure with SPS); SPAI = Social Phobia Anxiety Inventory (Turner, et al., 1989); SPIn = 
Social Phobia Inventory (Connor, et al., 2000); SPS = Social Phobia Scale (Mattick \& Clarke, 1998; NOTE: companion measure with SIAS). Other assessments: CCAPS-62 = Counselling Centre Assessment of Psychological Symptoms-62 (Locke et al., 2011); CIDI = Composite

International Diagnostic Interview (World Health Organisation, 1990); SCID = Structured Clinical Interview for DSM-IV (First, et al., 1995). 
Table 2

Risk of Bias Assessment

\begin{tabular}{|c|c|c|c|c|c|c|c|c|c|c|c|}
\hline Authors & $\begin{array}{l}\text { Unbiased } \\
\text { selection } \\
\text { of cohort }\end{array}$ & $\begin{array}{l}\text { Selection } \\
\text { minimises } \\
\text { baseline } \\
\text { differences } \\
*\end{array}$ & $\begin{array}{l}\text { Sample size } \\
\text { calculation/ } \\
\text { justification }\end{array}$ & $\begin{array}{l}\text { Adequate } \\
\text { description } \\
\text { of the } \\
\text { cohort }\end{array}$ & $\begin{array}{l}\text { Valid } \\
\text { method to } \\
\text { assess } \\
\text { attachment } \\
\text { style }\end{array}$ & $\begin{array}{l}\text { Valid } \\
\text { method } \\
\text { to assess } \\
\text { social } \\
\text { anxiety }\end{array}$ & $\begin{array}{l}\text { Assessors } \\
\text { blind to } \\
\text { SA or } \\
\text { attachment } \\
\text { status }\end{array}$ & $\begin{array}{l}\text { Adequate } \\
\text { follow- } \\
\text { up* }\end{array}$ & $\begin{array}{l}\text { Missing } \\
\text { data } \\
\text { minimal }\end{array}$ & $\begin{array}{l}\text { Control of } \\
\text { confounders }\end{array}$ & $\begin{array}{l}\text { Analysis } \\
\text { appropriate* }\end{array}$ \\
\hline $\begin{array}{l}\text { Aderka et } \\
\text { al. (2009) }\end{array}$ & Partial & N/A & No & Partial & Yes & Yes & Yes & N/A & Unclear & Yes & unclear \\
\hline $\begin{array}{l}\text { Anhalt \& } \\
\text { Morris } \\
(2008) \\
\end{array}$ & No & N/A & No & Yes & Yes & Yes & Yes & N/A & Unclear & Partial & unclear \\
\hline $\begin{array}{l}\text { Bifulco et } \\
\text { al. (2006) }\end{array}$ & Partial & N/A & $\mathrm{No}$ & $\mathrm{No}$ & Yes & Yes & No & Yes & Partial & $\mathrm{No}$ & unclear \\
\hline $\begin{array}{l}\text { Boelen, et } \\
\text { al. (2014) }\end{array}$ & No & N/A & No & Yes & Yes & Yes & unclear & N/A & Unclear & Yes & Yes \\
\hline $\begin{array}{l}\text { Bohlin \& } \\
\text { Hagekull } \\
(2009)\end{array}$ & Yes & N/A & $\mathrm{No}$ & Partial & Partial & Yes & Yes & Yes & Partial & Yes & unclear \\
\hline $\begin{array}{l}\text { Dağ, \& } \\
\text { Gülüm } \\
(2013)\end{array}$ & Unclear & Unclear & $\mathrm{No}$ & Partial & Yes & Yes & unclear & N/A & Unclear & Yes & Yes \\
\hline $\begin{array}{l}\text { Dakanalis } \\
\text { et al., } \\
(2014)\end{array}$ & Partial & N/A & Yes & Partial & Partial & Partial & Yes & N/A & Yes & no & unclear \\
\hline $\begin{array}{l}\text { Darcy, et } \\
\text { al. (2005) }\end{array}$ & Partial & N/A & No & Yes & Yes & Yes & Yes & N/A & Unclear & Yes & unclear \\
\hline
\end{tabular}




\begin{tabular}{|c|c|c|c|c|c|c|c|c|c|c|c|}
\hline $\begin{array}{l}\text { Eng et al., } \\
\text { (2001) }\end{array}$ & Yes & Yes & No & Yes & Yes & Yes & unclear & N/A & Unclear & Yes & unclear \\
\hline $\begin{array}{l}\text { Erozkan } \\
\text { (2009) }\end{array}$ & Unclear & N/A & No & No & Yes & Unclear & unclear & N/A & Unclear & No & unclear \\
\hline $\begin{array}{l}\text { Fan \& } \\
\text { Chang } \\
(2015) \\
\text { study } 2 \\
\end{array}$ & Partial & N/A & No & Yes & Yes & Yes & Yes & N/A & Unclear & Partial & unclear \\
\hline $\begin{array}{l}\text { Forston } \\
(2005)\end{array}$ & No & N/A & No & Yes & Yes & Yes & Yes & N/A & Yes & No & unclear \\
\hline $\begin{array}{l}\text { Gajwani, et } \\
\text { al. (2013) }\end{array}$ & Yes & N/A & No & Yes & Yes & Yes & Yes & N/A & Unclear & Partial & Yes \\
\hline $\begin{array}{l}\text { Greenwood } \\
(2008)\end{array}$ & Unclear & N/A & No & No & Yes & Partial & Yes & N/A & Yes & No & unclear \\
\hline $\begin{array}{l}\text { Gülüm \& } \\
\text { Dăg (2013) } \\
\text { study 1 }\end{array}$ & Unclear & Unclear & No & Partial & Yes & Yes & unclear & N/A & Unclear & Yes & Yes \\
\hline $\begin{array}{l}\text { Gülüm \& } \\
\text { Dăg (2013) } \\
\text { study } 2\end{array}$ & Unclear & Unclear & No & Partial & Yes & Yes & unclear & N/A & Unclear & Yes & Yes \\
\hline $\begin{array}{l}\text { Hoyer et } \\
\text { al., (2016) }\end{array}$ & Yes & N/A & Partial & Partial & Yes & Yes & unclear & N/A & Yes & No & unclear \\
\hline $\begin{array}{l}\text { Jordan } \\
(2010) \\
\end{array}$ & No & No & No & Yes & Yes & Yes & $\mathrm{N} / \mathrm{A}$ & N/A & Yes & No & Partial \\
\hline $\begin{array}{l}\text { Kashdan \& } \\
\text { Roberts } \\
(2011) \\
\end{array}$ & Yes & Yes & No & Yes & Partial & Yes & Yes & N/A & Yes & Yes & Yes \\
\hline Lionberg & Partial & No & No & Partial & Yes & Yes & unclear & N/A & Unclear & Partial & unclear \\
\hline
\end{tabular}




\begin{tabular}{|c|c|c|c|c|c|c|c|c|c|c|c|}
\hline $\begin{array}{l}(2003) \\
\text { study } 1\end{array}$ & & & & & & & & & & & \\
\hline $\begin{array}{l}\text { McDermott } \\
\text { et al., } \\
(2015)\end{array}$ & Yes & N/A & Partial & Yes & Yes & Yes & Yes & N/A & Yes & Yes & Yes \\
\hline $\begin{array}{l}\text { Michail \& } \\
\text { Birchwood } \\
(2014)\end{array}$ & Yes & Yes & No & Yes & Yes & Yes & unclear & N/A & Unclear & No & unclear \\
\hline $\begin{array}{l}\text { Mickelson, } \\
\text { et al. } \\
\text { (1997) }\end{array}$ & Yes & N/A & Partial & Yes & Partial & Yes & No & N/A & Yes & No & unclear \\
\hline $\begin{array}{l}\text { Nikitin \& } \\
\text { Freund } \\
\text { (2010) } \\
\text { study } 1\end{array}$ & Partial & N/A & $\mathrm{No}$ & Partial & Partial & Partial & Yes & N/A & Unclear & Partial & unclear \\
\hline $\begin{array}{l}\text { Parade, et } \\
\text { al. (2010) }\end{array}$ & No & Yes & No & Yes & Yes & Partial & Yes & Yes & Yes & No & Yes \\
\hline $\begin{array}{l}\text { Roring } \\
(2008)\end{array}$ & No & N/A & Unclear & Yes & No & Yes & Yes & N/A & Yes & No & unclear \\
\hline $\begin{array}{l}\text { van Buren } \\
\& \text { Cooley } \\
(2002)\end{array}$ & Partial & Unclear & $\mathrm{No}$ & Partial & Partial & Yes & Yes & N/A & Unclear & No & unclear \\
\hline $\begin{array}{l}\text { Weisman } \\
\text { et al. } \\
\text { (2011) } \\
\text { study } 1\end{array}$ & Partial & Yes & $\mathrm{No}$ & Partial & Yes & Yes & unclear & N/A & Unclear & Yes & unclear \\
\hline $\begin{array}{l}\text { Weisman } \\
\text { et al. } \\
(2011)\end{array}$ & Yes & Partial & Partial & Partial & Yes & Yes & unclear & N/A & Unclear & Yes & unclear \\
\hline
\end{tabular}


study 2

Weisman,

et al.,

(2011)

SEM

* Criteria only applicable to certain designs

Partial

Yes

Unclear

N/A

Unclear

Yes

Yes 
Table 3

Associations between Social Anxiety and Attachment Across Studies

\begin{tabular}{|c|c|c|c|c|c|}
\hline Study & Comparison & Attachment variable & Bivariate association & $\begin{array}{l}\text { Multivariate } \\
\text { association }\end{array}$ & Control variables \\
\hline \multirow{2}{*}{$\begin{array}{l}\text { Aderka, et } \\
\text { al., (2009) }\end{array}$} & \multirow[t]{2}{*}{ Spectrum of global social anxiety } & \multirow[t]{2}{*}{ Attachment insecurity } & $\mathrm{r}=.39 * *$ & - & - \\
\hline & & & - & $\begin{array}{l}\text { Non-significant } \\
\text { (values not reported) }\end{array}$ & $\begin{array}{l}\text { Social comparison; Submissive } \\
\text { behaviour }\end{array}$ \\
\hline $\begin{array}{l}\text { Anhalt \& } \\
\text { Morris } \\
(2008)\end{array}$ & Spectrum of global social anxiety & Attachment security & $\mathrm{r}=-.17 *-\mathrm{r}=-.21 * * *$ & $\beta=-.11-\beta=-.15$ & $\begin{array}{l}\text { Gender; perceived parenting } \\
\text { style; perceived attitudes } \\
\text { towards child rearing - } \\
\text { parenting behaviour }\end{array}$ \\
\hline \multirow{5}{*}{$\begin{array}{l}\text { Bifulco et } \\
\text { al. (2006) }\end{array}$} & \multirow[t]{5}{*}{ Social anxiety 'caseness' } & Attachment insecurity & $\mathrm{r}=.17 *$ & - & - \\
\hline & & Enmeshed attachment & $\mathrm{r}=.01$ & - & - \\
\hline & & Fearful attachment & $\mathrm{r}=.16 *$ & - & - \\
\hline & & $\begin{array}{l}\text { Angry-Dismissive } \\
\text { attachment }\end{array}$ & $\mathrm{r}=.10$ & - & - \\
\hline & & Withdrawn attachment & $r=.10^{a}$ & - & - \\
\hline \multirow[t]{2}{*}{$\begin{array}{l}\text { Boelen, et } \\
\text { al. (2014) }\end{array}$} & \multirow[t]{2}{*}{ Spectrum of global social anxiety } & Attachment anxiety & - & $\beta=.11$ & $\begin{array}{l}\text { Neuroticism; Attachment } \\
\text { avoidance; Prospective } \\
\text { intolerance of uncertainty; } \\
\text { Inhibitory intolerance of } \\
\text { uncertainty }\end{array}$ \\
\hline & & Attachment avoidance & - & $\beta=.10$ & $\begin{array}{l}\text { Neuroticism; Attachment } \\
\text { anxiety; Prospective intolerance } \\
\text { of uncertainty; Inhibitory } \\
\text { intolerance of uncertainty }\end{array}$ \\
\hline
\end{tabular}


Bohlin \& $\quad$ Social Interaction Anxiety and Social Attachment security $\quad$ Non-significant (values -

Hagekull Phobia combined into global social not reported)

(2009) anxiety measure

Dağ \& Spectrum of global social anxiety $\quad$ Attachment anxiety $\quad r=.23 * *-r=.26 * * \quad \beta=.06-\beta=.09 \quad$ Attachment avoidance;

Gülüm Cognitive flexibility

$(2013)^{b} \quad \quad$ Attachment avoidance $r=.21 * *-r=.29 * * \quad \beta=.16^{*}-\beta=.25 * * *$ Attachment anxiety; Cognitive flexibility

Dakanalis Spectrum of social interaction anxiety Attachment anxiety $\mathrm{r}=.52 * * *$

et al.,

(2014)

al. (2005)

preoccupied

attachment

$\mathrm{r}=.12-\mathrm{r}=.38 * * \quad \beta=.02-\beta=.26^{* *}$



$\beta=-.04-\beta=.18 * \quad$ Trait anxiety; Fearful

attachment

$\beta=-.02-\beta=.25 * * \quad$ Anxiety sensitivity; Fearful attachment

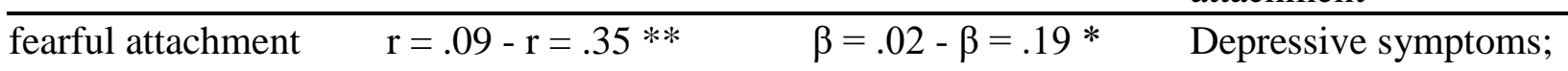
preoccupied attachment

$\beta=.04-\beta=.11 \quad$ Trait anxiety; preoccupied attachment

$\beta=.02-\beta=.16^{*} \quad$ Anxiety sensitivity; preoccupied attachment

Eng et al., Social anxiety 'caseness' Vs. healthy Attachment security $d=-.49 *-d=-1.16 * * *-$ (2001) control
Groups matched on: Age;

Gender; Race; Psychosis;

Bipolar disorder; Organic mental disorders; Active substance dependence (within 
last 3 months)

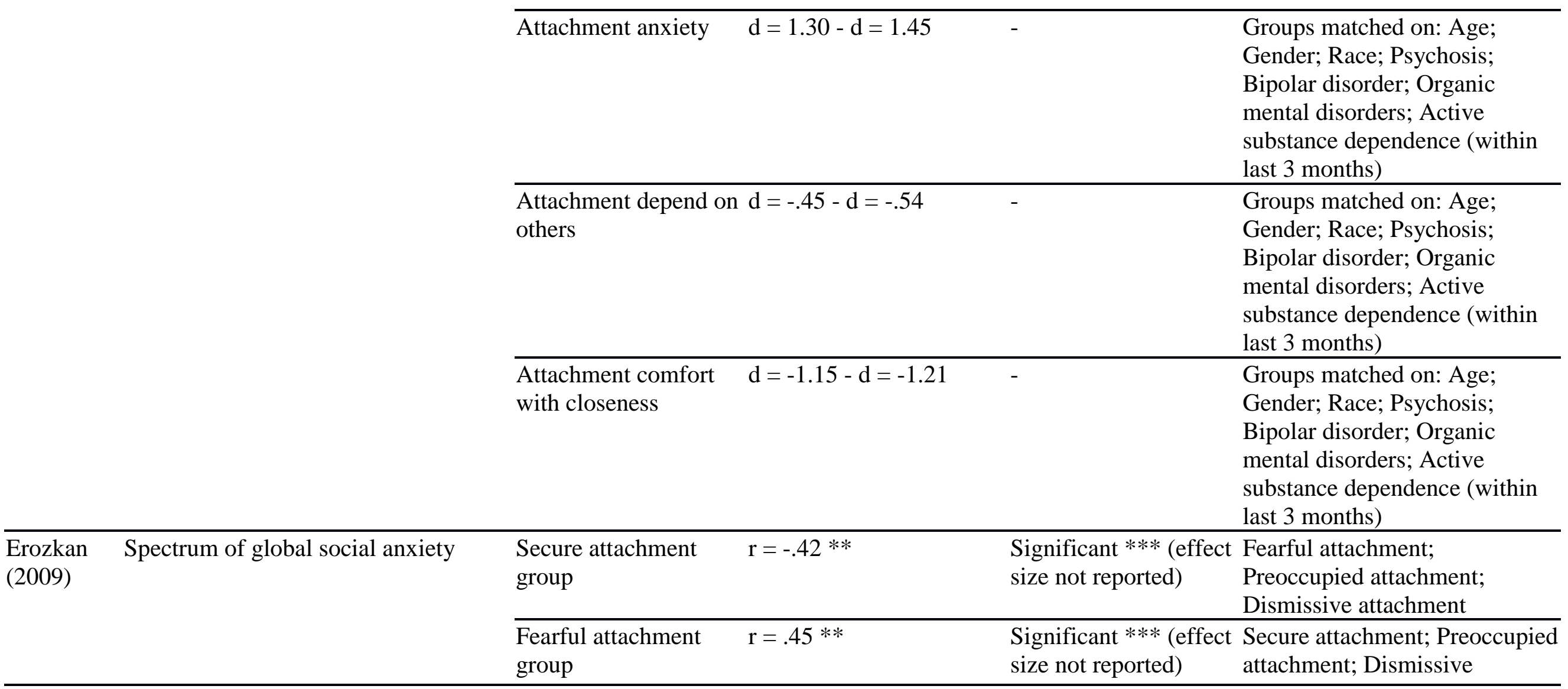


attachment

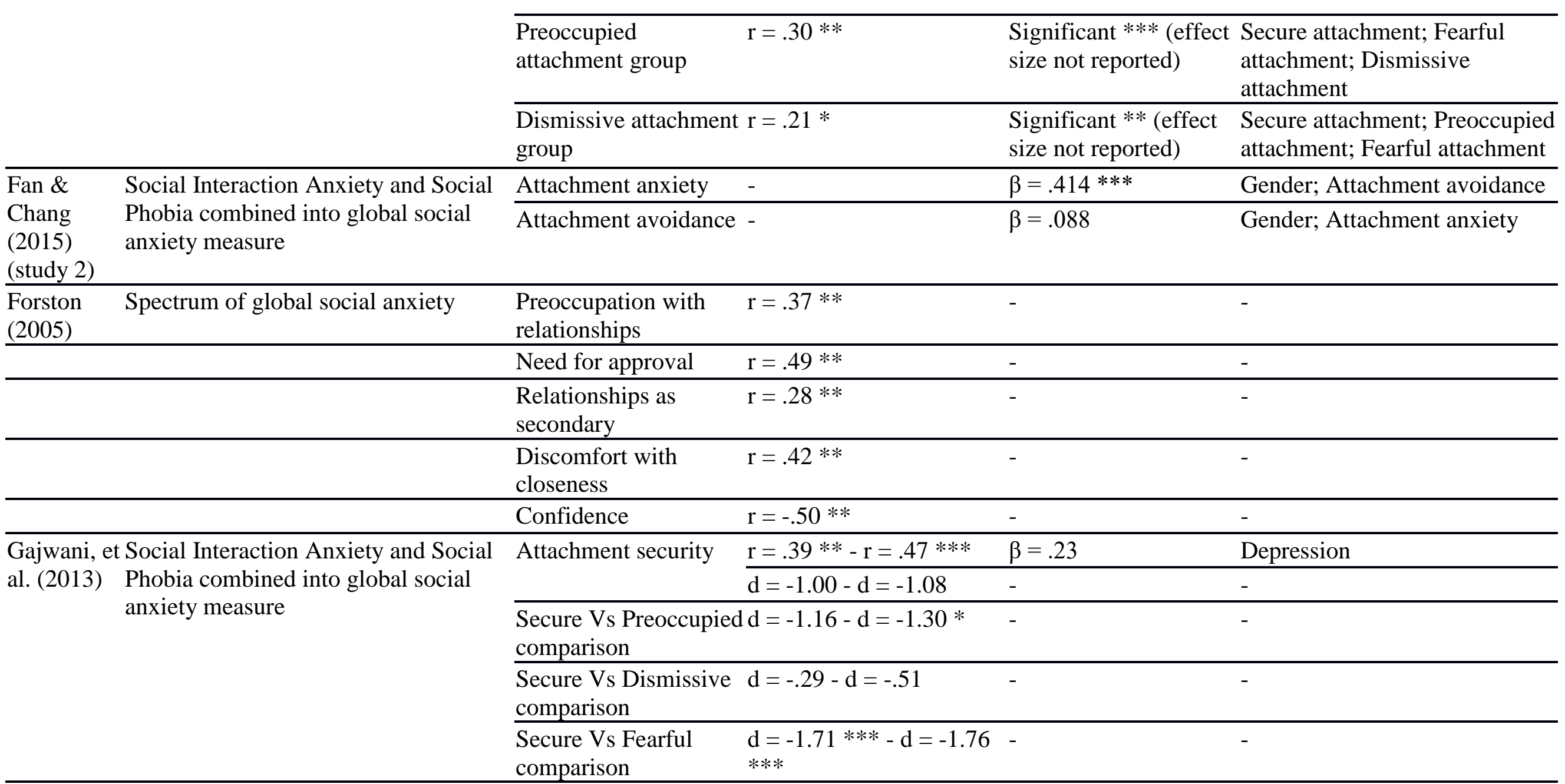




\begin{tabular}{|c|c|c|c|c|}
\hline \multirow{2}{*}{$\begin{array}{l}\text { Greenwood Public and private self-consciousness } \\
\text { (2008) }\end{array}$} & Attachment anxiety & $\mathrm{r}=.28 * *$ & - & - \\
\hline & Attachment avoidance & $\mathrm{r}=.02$ & - & - \\
\hline \multirow{2}{*}{$\begin{array}{l}\text { Gülüm \& Spectrum of global social anxiety } \\
\text { Dağ (2013) } \\
\text { study } 1^{\text {b }}\end{array}$} & Attachment anxiety & $\mathrm{r}=.23 * *-\mathrm{r}=.26 * *$ & $\beta=.16 * *-\beta=.19 * *$ & $\begin{array}{l}\text { Locus of control; Attachment } \\
\text { avoidance }\end{array}$ \\
\hline & Attachment avoidance & $\mathrm{r}=.21 * *-\mathrm{r}=.29 * *$ & $\beta=.17 * *-\beta=.28 * *$ & $\begin{array}{l}\text { Locus of control; Attachment } \\
\text { anxiety }\end{array}$ \\
\hline \multirow{2}{*}{$\begin{array}{l}\text { Gülüm \& S } \\
\text { Dağ (2013) } \\
\text { study } 2\end{array}$} & Attachment anxiety & $\mathrm{r}=.24 * *-\mathrm{r}=.25 * *$ & $\beta=.14 * *-\beta=.16 * *$ & $\begin{array}{l}\text { Repetitive thinking; } \\
\text { Attachment avoidance }\end{array}$ \\
\hline & Attachment avoidance & $\mathrm{r}=.22 * *-\mathrm{r}=.33 * *$ & $\beta=.21 * *-\beta=.33 * *$ & $\begin{array}{l}\text { Repetitive thinking; } \\
\text { Attachment anxiety }\end{array}$ \\
\hline \multirow[t]{2}{*}{$\begin{array}{l}\text { Hoyer et Spectrum of global social anxiety } \\
\text { al., (2016) }\end{array}$} & Attachment anxiety & $\mathrm{r}=.20 * *$ & - & - \\
\hline & Attachment avoidance & $\mathrm{r}=.22 * *$ & - & - \\
\hline $\begin{array}{l}\text { Jordan } \\
(2010)\end{array}$ & Attachment insecurity & $\mathrm{r}=.616 * *$ & - & - \\
\hline \multirow[t]{2}{*}{$\begin{array}{l}\text { Kashdan \& Spectrum of global social anxiety } \\
\text { Roberts } \\
(2011)\end{array}$} & Attachment anxiety & $\begin{array}{l}\text { No significant difference } \\
\text { in attachment anxiety to } \\
\text { therapy group between } \\
\text { SA \& no SA groups } \\
\text { (values not reported) }\end{array}$ & - & $\begin{array}{l}\text { SA and no SA groups matched } \\
\text { on: clinically relevant } \\
\text { depression; treatment } \\
\text { completion; Age; Gender; } \\
\text { Ethnicity }\end{array}$ \\
\hline & Attachment avoidance & $\begin{array}{l}\text { No significant difference } \\
\text { in attachment avoidance } \\
\text { to therapy group between } \\
\text { SA \& no SA groups } \\
\text { (values not reported) }\end{array}$ & - & $\begin{array}{l}\text { SA and no SA groups matched } \\
\text { on: clinically relevant } \\
\text { depression; treatment } \\
\text { completion; Age; Gender; } \\
\text { Ethnicity }\end{array}$ \\
\hline
\end{tabular}




\begin{tabular}{|c|c|c|c|c|c|}
\hline \multirow[t]{8}{*}{$\begin{array}{l}\text { Lionberg } \\
(2003) \\
\text { study } 1\end{array}$} & $\begin{array}{l}\text { Social anxiety 'caseness' Vs. healthy } \\
\text { control (total participants) }\end{array}$ & $\begin{array}{l}\text { Attachment comfort } \\
\text { with closeness }\end{array}$ & $\mathrm{d}=-1.44 * *$ & - & \multirow{8}{*}{$\begin{array}{l}\text { Social anxiety and healthy } \\
\text { control groups matched on: } \\
\text { Age; Gender; Ethnicity; } \\
\text {-Parental marital status; } \\
\text { Participant relationship status; } \\
\text { Participant relationship } \\
\text {-duration; Schizophrenia } \\
\text { diagnosis; MDD; OCD; } \\
\text { substance dependence } \\
\text { diagnosis; organic psychiatric } \\
\text {-disorders; high suicide risk; } \\
\text { Social anxiety and panic } \\
\text { disorder groups matched on: } \\
\text {-Age; Ethnicity; Parental marital } \\
\text { status; Participant relationship } \\
\text { status; Participant relationship } \\
\text { _duration; Treatment seeking for } \\
\text { anxiety; Schizophrenia } \\
\text { diagnosis; MDD; OCD; } \\
\text { substance dependence } \\
\text {-diagnosis; organic psychiatric } \\
\text { disorders; high suicide risk; }\end{array}$} \\
\hline & $\begin{array}{l}\text { Social anxiety 'caseness' Vs. Vs. } \\
\text { healthy control (female participants } \\
\text { only) }\end{array}$ & & $\mathrm{d}=-1.03 *$ & - & \\
\hline & $\begin{array}{l}\text { Social anxiety 'caseness' Vs. Panic } \\
\text { disorder 'caseness' (female participants } \\
\text { only) }\end{array}$ & & $\mathrm{d}=-.71 *$ & - & \\
\hline & $\begin{array}{l}\text { Social anxiety 'caseness' Vs. healthy } \\
\text { control (total participants) }\end{array}$ & \multirow[t]{3}{*}{$\begin{array}{l}\text { Attachment depend or } \\
\text { others }\end{array}$} & $\mathrm{d}=-1.02 * *$ & - & \\
\hline & $\begin{array}{l}\text { Social anxiety 'caseness' Vs. Vs. } \\
\text { healthy control (female participants } \\
\text { only) }\end{array}$ & & $\mathrm{d}=-.83 *$ & - & \\
\hline & $\begin{array}{l}\text { Social anxiety 'caseness' Vs. Panic } \\
\text { disorder 'caseness' (female participants } \\
\text { only) }\end{array}$ & & $\mathrm{d}=-.33$ & - & \\
\hline & $\begin{array}{l}\text { Social anxiety 'caseness' Vs. healthy } \\
\text { control (total participants) }\end{array}$ & \multirow[t]{2}{*}{ Attachment anxiety } & $\mathrm{d}=1.32 *$ & - & \\
\hline & $\begin{array}{l}\text { Social anxiety 'caseness' Vs. Vs. } \\
\text { healthy control (female participants } \\
\text { only) }\end{array}$ & & $\mathrm{d}=1.33^{*}$ & - & \\
\hline
\end{tabular}


Social anxiety 'caseness' Vs. Panic

$d=0.06$

disorder 'caseness' (female participants

only)

\begin{tabular}{|c|c|c|c|c|}
\hline \multirow{2}{*}{$\begin{array}{l}\text { McDermott Spectrum of global social anxiety } \\
\text { et al., } \\
(2015) \\
\end{array}$} & Attachment anxiety & $\mathrm{r}=.40 * * * \mathrm{c}$ & $\beta=.21 * * *$ & Attachment avoidance; Hope \\
\hline & Attachment avoidance & $\mathrm{r}=.27 * * * \mathrm{c}$ & $\beta=.06 * *$ & Attachment anxiety; Hope \\
\hline \multirow{4}{*}{$\begin{array}{ll}\text { Michail \& } & \text { Social Interaction Anxiety and Social } \\
\text { Birchwood Phobia combined into global social } \\
(2014) \quad \text { anxiety measure }\end{array}$} & $\begin{array}{l}\text { Insecure attachment } \\
\text { overall }\end{array}$ & $\mathrm{OR}=18.5^{\mathrm{e}}$ & - & - \\
\hline & $\begin{array}{l}\text { Preoccupied } \\
\text { attachment }\end{array}$ & $\mathrm{OR}=1.5^{\mathrm{e}}$ & - & - \\
\hline & Dismissive attachment & $\mathrm{OR}=0.4^{\mathrm{e}}$ & - & - \\
\hline & Fearful attachment & $\mathrm{OR}=23.2^{\mathrm{e}}$ & - & - \\
\hline \multirow[t]{4}{*}{$\begin{array}{l}\text { Mickelson, Social anxiety 'caseness' } \\
\text { et al. } \\
(1997)\end{array}$} & $\begin{array}{l}\text { Secure attachment } \\
\text { group }\end{array}$ & $\begin{array}{l}\text { Significant } * * * \\
\text { (standardised effect size } \\
\text { not reported) }\end{array}$ & - & - \\
\hline & $\begin{array}{l}\text { anxious attachment } \\
\text { group }\end{array}$ & $\begin{array}{l}\text { Significant } * * * \\
\text { (standardised effect size } \\
\text { not reported) }\end{array}$ & - & - \\
\hline & $\begin{array}{l}\text { avoidant attachment } \\
\text { group }\end{array}$ & $\begin{array}{l}\text { Significant } * * * \\
\text { (standardised effect size } \\
\text { not reported) }\end{array}$ & - & - \\
\hline & $\begin{array}{l}\text { anxious/avoidant } \\
\text { attachment comparison }\end{array}$ & $\begin{array}{l}\text { Non-significant } \\
\text { (standardised effect size } \\
\text { not reported) }\end{array}$ & - & - \\
\hline
\end{tabular}




\begin{tabular}{|c|c|c|c|c|c|}
\hline \multirow[t]{4}{*}{$\begin{array}{l}\text { Nikitin \& } \\
\text { Freund } \\
\text { (2010) } \\
\text { (study 1) }\end{array}$} & Spectrum of social interaction anxiety & secure attachment & - & $\beta=-.48 * * *$ & $\begin{array}{l}\text { Preoccupied attachment; } \\
\text { Dismissive attachment; Fearful } \\
\text { attachment; Social approach } \\
\text { motivation; Social avoidance } \\
\text { motivation; Social approach X } \\
\text { avoidance motivation } \\
\text { interaction }\end{array}$ \\
\hline & & $\begin{array}{l}\text { Preoccupied } \\
\text { attachment }\end{array}$ & - & $\begin{array}{l}\text { Non-significant } \\
\text { (values not reported) }\end{array}$ & $\begin{array}{l}\text { Secure attachment; Dismissive } \\
\text { attachment; Fearful attachment; } \\
\text { Social approach motivation; } \\
\text { Social avoidance motivation; } \\
\text { Social approach X avoidance } \\
\text { motivation interaction }\end{array}$ \\
\hline & & Dismissive attachment & & $\begin{array}{l}\text { Non-significant } \\
\text { (values not reported) }\end{array}$ & $\begin{array}{l}\text { Secure attachment; Preoccupied } \\
\text { attachment; Fearful attachment; } \\
\text { Social approach motivation; } \\
\text { Social avoidance motivation; } \\
\text { Social approach X avoidance } \\
\text { motivation interaction }\end{array}$ \\
\hline & & Fearful attachment & - & $\begin{array}{l}\text { Non-significant } \\
\text { (values not reported) }\end{array}$ & $\begin{array}{l}\text { Secure attachment; Preoccupied } \\
\text { attachment; Dismissive } \\
\text { attachment; Social approach } \\
\text { motivation; Social avoidance } \\
\text { motivation; Social approach X } \\
\text { avoidance motivation } \\
\text { interaction }\end{array}$ \\
\hline
\end{tabular}




\begin{tabular}{|c|c|c|c|c|c|}
\hline $\begin{array}{l}\text { Parade, et } \\
\text { al. (2010) }\end{array}$ & Spectrum of social interaction anxiety & Attachment security & $\mathrm{r}=-.25 * *$ & $\beta=-.14$ & Ethnicity \\
\hline \multirow[t]{5}{*}{$\begin{array}{l}\text { Roring } \\
\text { (2008) }\end{array}$} & $\begin{array}{l}\text { Social Interaction Anxiety and Social } \\
\text { Phobia combined into global social } \\
\text { anxiety measure }\end{array}$ & Overall attachment & - & $\begin{array}{l}\text { Significant predictor } \\
\text { of SIAS \& SPS } \\
\text { (standardised values } \\
\text { not reported) } * *\end{array}$ & Perceived social support \\
\hline & & Secure attachment & $\mathrm{r}=-.25 * *-\mathrm{r}=-.44 * *$ & $\begin{array}{l}\text { Significant predictor } \\
\text { of SIAS (standardised } \\
\text { values not reported) ** } \\
\end{array}$ & $\begin{array}{l}\text { Fearful attachment; } \\
\text { Preoccupied attachment; } \\
\text { Dismissing attachment } \\
\end{array}$ \\
\hline & & Fearful attachment & $\mathrm{r}=.28 * *-\mathrm{r}=.33 * *$ & $\begin{array}{l}\text { Significant predictor } \\
\text { of SPS (standardised } \\
\text { values not reported) } * *\end{array}$ & $\begin{array}{l}\text { Secure attachment; Preoccupied } \\
\text { attachment; Dismissing } \\
\text { attachment }\end{array}$ \\
\hline & & $\begin{array}{l}\text { Preoccupied } \\
\text { attachment }\end{array}$ & $\mathrm{r}=.19 * *-\mathrm{r}=.26 * *$ & $\begin{array}{l}\text { Significant predictor } \\
\text { of SIAS (standardised } \\
\text { values not reported) } * * \\
\end{array}$ & $\begin{array}{l}\text { Secure attachment; Fearful } \\
\text { attachment; Dismissing } \\
\text { attachment }\end{array}$ \\
\hline & & Dismissing attachment & $\mathrm{r}=.05-\mathrm{r}=.06$ & $\begin{array}{l}\text { Non-significant } \\
\text { (values not reported) }\end{array}$ & $\begin{array}{l}\text { Fearful attachment; } \\
\text { Preoccupied attachment; } \\
\text { Dismissing attachment }\end{array}$ \\
\hline \multirow[t]{2}{*}{$\begin{array}{l}\text { van Buren } \\
\& \text { Cooley } \\
(2002)\end{array}$} & Spectrum of global social anxiety & $\begin{array}{l}\text { Secure attachment } \\
\text { group Vs. Preoccupied } \\
\text { attachment group } \\
\end{array}$ & $\mathrm{d}=-.86^{\mathrm{z}}$ & - & - \\
\hline & & $\begin{array}{l}\text { Secure attachment } \\
\text { group Vs. Dismissive } \\
\text { attachment group }\end{array}$ & $d=-.36^{z}$ & - & - \\
\hline
\end{tabular}




\begin{tabular}{|c|c|c|c|}
\hline & $\begin{array}{l}\text { Secure attachment } \quad \mathrm{d}=-.88^{\mathrm{z}} \\
\text { group Vs. Fearful } \\
\text { attachment group }\end{array}$ & - & - \\
\hline \multirow[t]{2}{*}{$\begin{array}{l}\text { Weisman, Spectrum of global social anxiety } \\
\text { et al., } \\
\text { (2011) } \\
\text { (Study 1) }\end{array}$} & Attachment anxiety $\quad \mathrm{d}=1.15$ & - & $\begin{array}{l}\text { Groups matched on: Age; } \\
\text { Gender; Marital status; } \\
\text { Occupational status; } \\
\text { Schizophrenia diagnosis; MDD } \\
\text { (excluded); substance } \\
\text { dependence diagnosis; }\end{array}$ \\
\hline & Attachment avoidance $\mathrm{d}=1.15 * *$ & - & $\begin{array}{l}\text { Groups matched on: Age; } \\
\text { Gender; Marital status; } \\
\text { Occupational status; } \\
\text { Schizophrenia diagnosis; MDD } \\
\text { (excluded); substance } \\
\text { dependence diagnosis; }\end{array}$ \\
\hline \multirow[t]{2}{*}{$\begin{array}{l}\text { Weisman, Spectrum of global social anxiety } \\
\text { et al., } \\
\text { (2011) } \\
\text { (Study 2) }\end{array}$} & Attachment anxiety $\quad \mathrm{d}=0$ & - & $\begin{array}{l}\text { Groups matched on: Gender; } \\
\text { years of education; Depression } \\
\text { (included); Schizophrenia } \\
\text { diagnosis; substance } \\
\text { dependence diagnosis; } \\
\text { treatment seeking for anxiety }\end{array}$ \\
\hline & Attachment avoidance $\mathrm{d}=1.38$ & - & $\begin{array}{l}\text { Groups matched on: Gender; } \\
\text { years of education; Depression } \\
\text { (included); Schizophrenia } \\
\text { diagnosis; substance } \\
\text { dependence diagnosis; } \\
\text { treatment seeking for anxiety }\end{array}$ \\
\hline $\begin{array}{l}\text { Weisman, Spectrum of global social anxiety } \\
\text { et al., }\end{array}$ & Attachment anxiety & $\beta=.21 *$ & $\begin{array}{l}\text { Attachment avoidance; } \\
\text { Submissive behaviour; Social }\end{array}$ \\
\hline
\end{tabular}


NOTE: MDD = Major Depressive Disorder; OCD = Obsessive Compulsive Disorder;

$*=\mathrm{p}<.05 ; * *=\mathrm{p}<.01 ; * * *=\mathrm{p}<.001 ; \mathrm{z}=$ significance not reported $\mathrm{a}=$ value corrected from published article through contact with author

$\mathrm{b}=$ studies used the same population

$\mathrm{c}=$ latent variables correlated

$d=$ Cohen's d (Cohen, 1992); all Cohen's d effect sizes calculated from study data, but not reported in original paper

$\mathrm{e}=$ Values calculated with very low cell numbers; interpret with caution

$\mathrm{r}=$ correlation coefficient

$\beta=$ standardised regression coefficient 


\section{Appendix A: Email sent to included authors and important authors in the field seeking further publications to consider for inclusion}

Dear Insert author's name here,

We are currently undertaking a systematic review of the research literature concerning the relationship between attachment and social anxiety disorder. During our literature search we identified your paper, entitled "Insert relevant paper title here" which appears relevant to our review. I am emailing to check if you have undertaken any further work, either published or unpublished, which meets the following criteria:

- Uses quantitative measures of attachment and social anxiety/social phobia

- The association between Attachment and social anxiety data is analysed

- Adult population (e.g, sample aged 18 years or over)

If so, we would greatly appreciate it if you could send us any articles/reports relating to this work to consider for inclusion in this review. Many thanks for your time.

Ray Manning

Trainee clinical psychologist

Doctorate in Clinical Psychology programme

University of Liverpool

Whelan Building

Quadrangle

Brownlow Hill

Liverpool

L69 3GB 


\section{Appendix B: Systematic Review Quality Assessment Tool}

\section{Quality of observational studies}

General instructions: Grade each criterion as "Yes," "No," "Partially," or "Unsure." Factors to consider when making an assessment are listed under each criterion. Note that some criteria will only apply to specify types of study. For example, power calculations are relevant for studies aiming to compare attachment or social anxiety between two groups, or studies that look at correlates of social anxiety in an insecurely attached sample. However, power calculations are not relevant in an uncontrolled study of a single socially anxious sample where attachment related data is only described (rather than featuring in any inferential statistics). Where a criterion only applies to a specific design, it is in italics.

1. Unbiased selection of the cohort?

Factors that help reduce selection bias:

- Inclusion/exclusion criteria

- Clearly described

- Criteria for separating groups based on social anxiety or attachment style are stated or referred to in reference to past research

- Recruitment strategy

- Clearly described

- Sample is representative of the population of interest: How representative of the general population is the study sample (i.e. people with social anxiety sampled represents all people with social anxiety)

2. Selection minimizes baseline differences in demographic factors (For controlled studies only)?

Factors to consider:

- Was selection of the comparison group appropriate? Consider whether these two sources are likely to differ on factors related to the outcome (other than degree of social anxiety or attachment style). Note that in instances of attachment insecurity or social anxiety versus secure or non-clinical controls, differences in clinical characteristics may be expected, but matching on key demographics (age, gender, ethnicity, education, etc.) would still be required to minimize bias.

- Did the study investigators do other things to ensure that exposed/unexposed groups were comparable, e.g., by using stratification or propensity scores?

3. Sample size calculated (for controlled studies and where studies test for predictors/correlates of social anxiety/attachment style)?

Factors to consider:

- Did the authors report conducting a power analysis or describe some other basis for determining the adequacy of study group sizes for the primary outcome(s) of interest to us?

- Did the eventual sample size deviate by $\leq 10 \%$ of the sample size suggested by the power calculation?

4. Adequate description of the cohort?

Consider whether the cohort is well-characterized in terms of baseline demographics?

- Consider key demographic information such as age, gender and ethnicity.

- Information regarding education or socio-economic characteristics is also important.

5. Validated assessment of attachment style? 
Factors to consider:

- Was the method used to ascertain attachment style clearly described? (Details should be sufficient to permit replication in new studies)

- Was a valid and reliable measure used to assess attachment? (self-report measures tend to have lower reliability and validity than clinical interview). Gold standard tools include the Adult Attachment Interview (AAI).

6. Validated method for assessing social anxiety?

Factors to consider:

- Was social anxiety assessed using valid and reliable measures? Note that measures that consist of subscales taken from larger measures, or scales intended for use in conjunction with other scales may lack content validity and reliability, failing to capture social anxiety and social phobia symptoms comprehensively. Gold standard tools include the Anxiety Disorders Interview Schedule (ADIS) and the Structured Clinical Interview for DSM-IV (SCID).

- Were these measures implemented consistently across all study participants?

7. Outcome assessment blind to exposure?

- Were the study investigators who assessed outcomes blind to the UHR status of participants? (Note that even in single-arm studies so degree of blinding is possible, for example using external interviewers with no knowledge of participants clinical status).

8. Adequate follow-up period (longitudinal studies only)?

Factors to consider:

- Follow-up for effects of intervention is required to assess endurance of clinical change.

9. Missing data

Factors to consider:

- Did missing data from any group exceed $20 \%$ ?

- In longitudinal studies consider attrition over time as a form of missing data. Note that the criteria of $<20 \%$ missing data may be unrealistic over longer follow-up periods.

- If missing data is present and substantial, were steps taken to minimize bias (e.g., sensitivity analysis or imputation).

10. Analysis controls for confounding (controlled studies and where studies test for predictors/correlates of attachment style or social anxiety)?

Factors to consider for controlled studies:

- Does the study identify and control for important confounding variables and effect modifiers? Confounding variables are risk factors that are correlated with attachment style and social anxiety and may therefore bias the estimation of the effect of attachment on social anxiety if unmeasured. These may include demographic and clinical variables (e.g., co-morbidity).

11. Factors to consider for studies looking at predictors of social anxiety within insecurely attached groups:

○ Did the study control for likely demographic and clinical confounders? For example, using multiple regression to adjust for demographic or clinical factors likely to be correlated with predictor and outcome?

12. Analytic methods appropriate (Controlled studies and where studies test for predictors/correlates of attachment style and social anxiety)?

Factors to consider: 
- Was the kind of analysis done appropriate for the kind of outcome data (categorical, continuous, etc.)?

- Was the number of variables used in the analysis appropriate for the sample size? (The statistical techniques used must be appropriate to the data and take into account issues such as controlling for small sample size, clustering, rare outcomes, multiple comparison, and number of covariates for a given sample size) 